\title{
Malvaceae do Parque Estadual do Ibitipoca, Estado de Minas Gerais, Brasil
}

\author{
Aluisio José Fernandes-Júnior ${ }^{1,2,3,5}$ e Tatiana Ungaretti Paleo Konno ${ }^{4}$
}

Recebido: 29.11.2016; aceito: 9.07.2017

\begin{abstract}
Malvaceae of Parque Estadual do Ibitipoca, Minas Gerais State, Brazil). The Parque Estadual do Ibitipoca is located in the southeast of Minas Gerais State, and presents mainly the rocky field vegetation type. Twenty species and 10 genera of Malvaceae were recorded in the Parque. Sida was the richest genus with eight species, followed by Triumfetta with three species. An identification key for species, as well as morphological descriptions and illustrations are provided.
\end{abstract}

Keywords: Atlantic Forest, floristic, rocky field, Sida, taxonomy

RESUMO - (Malvaceae do Parque Estadual do Ibitipoca, Estado de Minas Gerais, Brasil). O Parque Estadual do Ibitipoca localiza-se no sudeste do Estado de Minas Gerais e apresenta principalmente vegetação típica de campo rupestre. Foram encontradas 20 espécies de Malvaceae, distribuídas em 10 gêneros. O gênero Sida foi o mais representativo com oito espécies, seguido de Triumfetta com três espécies. Uma chave de identificação para as espécies, descrições morfológicas e ilustrações são apresentadas.

Palavras-chave: campo rupestre, Floresta Atlântica, florística, Sida, taxonomia

\section{Introdução}

Malvaceae compreende as tradicionais famílias da ordem Malvales: Bombacaceae, Sterculiaceae, Tiliaceae e Malvaceae (Cronquist 1988, APG IV 2016). Nesta circunscrição, Malvaceae é monofilética e está dividida em nove subfamílias, apresentando como sinapomorfia morfológica um nectário constituído de tricomas glandulares multicelulares, localizado internamente na base do cálice (Judd \& Manchester 1997, Alverson et al. 1999, Bayer et al. 1999, Nyffeler et al. 2005, APG IV 2016). Além disso, outras possíveis sinapomorfias como indumento formado por tricomas estrelados, cálice com prefloração valvar, células do raio dilatadas em forma de cunha e inflorescências constituídas de unidades cimosas modificadas devem ser melhor estudadas (Judd \& Manchester 1997, Bayer et al. 1999, Simpson 2006).

Malvaceae possui 243 gêneros e 4.300 espécies distribuídas principalmente nas regiões tropicais e subtropicais e, mais raramente, nas regiões temperadas (Bayer \& Kubitzki 2003). No Brasil, a família está representada por 70 gêneros e 765 espécies, 406 destas endêmicas (BFG 2015).

Malvaceae possui vários gêneros com representantes de importância econômica como Gossypium (algodão), Abelmonchus (quiabo), Theobroma (cacau, cupuaçu), Hibiscus (vinagreira, hibisco), Malvaviscus (malvavisco), Tilia (tília), Durio (durian) e Ceiba (paineiras) (Simpson 2006, Lorenzi 2008). Algumas espécies de Anoda, Malvastrum, Sida, Triumfetta e Waltheria são invasoras de culturas e destacam-se como ruderais (Lorenzi 2008).

A diversidade de Malvaceae no Estado de Minas Gerais reserva lacunas, sendo que poucos trabalhos de cunho florístico foram realizados como na Flora da Serra do Cipó (Esteves 1986), Parque Estadual do Rio Doce (Bovini et al. 2001) e na Serra de Grão-Mogol (Esteves 2003, Esteves \& Ferrucci 2006, Cristóbal 2006, Esteves \& Krapovickas 2009).

1. Parte da Dissertação de Mestrado do primeiro Autor

2. Universidade Federal do Rio de Janeiro, Museu Nacional, Quinta da Boa Vista, São Cristóvão 20940-040, Rio de Janeiro, RJ, Brasil

3. Museu Paraense Emílio Goeldi, Coordenação de Botânica, Campus de Pesquisa, Avenida Perimetral, 1.901, 66077-830 Belém, PA, Brasil

4. Universidade Federal do Rio de Janeiro, Núcleo em Ecologia e Desenvolvimento Sócio Ambiental de Macaé, Avenida São José do Barreto, 764, 27965-045 Macaé, RJ, Brasil

5. Autor para correspondência: ajfernandesjunior@gmail.com 
Deste modo, com o escasso conhecimento das Malvaceae no estado de Minas Gerais, este trabalho teve o objetivo de inventariar as espécies de Malvaceae ocorrentes no Parque Estadual do Ibitipoca, incluindo descrições morfológicas, ilustrações e chave de identificação para as espécies.

\section{Material e métodos}

O Parque Estadual do Ibitipoca (PEIB) situa-se no sudeste de Minas Gerais nos municípios de Santa Rita do Ibitipoca e Lima Duarte (figura 1) e abrange uma área de 1.923,5 hectares (Forzza et al. 2013). O PEIB encontra-se na parte alta da chamada Serra do Ibitipoca, em altitudes que variam de 1.050 a 1.784 m (Silva \& Zaidan 2004). O clima da região é o mesotérmico úmido (Cwb) de acordo com a classificação de Köppen e a precipitação anual média é de $1532 \mathrm{~mm}$ e a temperatura média é de $18,9^{\circ} \mathrm{C}$ (CETEC 1983).

Costa et al. (1998) classificaram o PEIB na categoria de "Extrema Importância Biológica", em razão do endemismo de anfíbios, mamíferos e aves ameaçados, da relevância da singularidade espeleológica e da diversidade de habitats. A vegetação da Serra do Ibitipoca representa um refúgio vegetacional, uma vez que difere florística e fisionomicamente da flora dominante da região, pelas características geológicas e ecológicas, formando uma ilha destoante da vegetação clímax circundante (Salimena 1996).

Foram realizadas expedições mensais entre outubro de 2009 e setembro de 2010, contemplando as diferentes regiões do PEIB. Os materiais coletados foram depositados nos herbários R e CESJ, além de realizar consultas aos herbários BHCB, CESJ, HB, R, RB, RFA, SP e SPF (acrônimos de acordo com Thiers 2016). A identificação dos espécimes baseou-se na literatura específica, incluindo obra princeps, e comparação de espécimes de herbário. As descrições morfológicas seguiram a terminologia proposta por Cristóbal (2001), Cunha (1985), Harris \& Harris (2001), Krapovickas \& Cristóbal (1965) e Lay (1950).

Descrições morfológicas das estruturas vegetativas e reprodutivas, chaves de identificação e ilustrações foram elaboradas a partir das coletas em campo e, quando necessário, complementadas com dados de coleções de herbário. Os dados referentes à distribuição geográfica das espécies no Brasil foram retirados de: Bovini 2016, Bovini et al. 2016, Cristóbal 2001, Cunha 1985, Krapovickas \& Cristóbal 1965, Krapovickas 2007, Lay 1950).

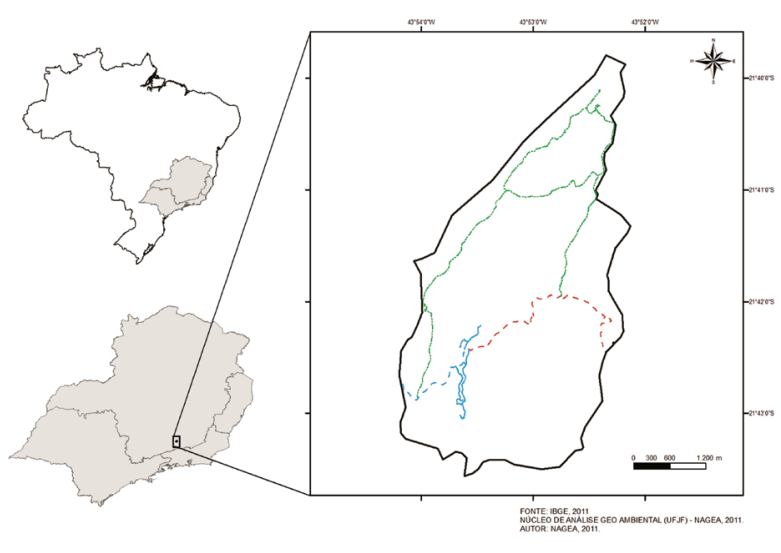

Figura 1. Localização do Parque Estadual do Ibitipoca e dos três circuitos turísticos: Circuito das Águas (linha azul), Circuito da Janela do Céu (linha verde) e Circuito do Pião (linha vermelha).

Figure 1. Location of the Ibitipoca State Park and its three tourist itinerary: Circuito das Águas (blue line), Circuito da Janela do Céu (green line) and Circuito do Pião (red line).

\section{Resultados e Discussão}

Neste estudo, foram reconhecidas 20 espécies de Malvaceae distribuídas em 10 gêneros: Callianthe, Helicteres, Hibiscus, Luehea, Pavonia, Peltaea, Sida, Triumfetta, Waltheria e Wissadula. O gênero Sida mostrou-se o mais abundante com oito espécies, seguido de Triumfetta, com três espécies. Desta forma, 16 espécies e 6 gêneros foram acrescidos a lista previamente publicada para o PEIB por Salimena (1996).

Malvaceae Juss. Gen. P1. 271. 1789.

Arvoretas, arbustos ou subarbustos eretos, decumbentes ou prostrados. Ramos cilíndricos ou aplanados, tricomas simples, glandulares e/ ou estrelados. Folhas alternas, espiraladas ou dísticas, simples e pecioladas; lâminas cartáceas ou membranáceas, inteiras ou lobadas, crenadas ou serreadas; venação palmada, 3-9-nervadas na base; nectários extraflorais presentes ou não; estípulas presentes, às vezes caducas. Flores solitárias ou em diversos tipos de inflorescência, axilares ou terminais; actinomorfas ou zigomorfas, hermafroditas; epicálice frequentemente presente; cálice gamossépalo ou dialissépalo, costados ou não, 5 sépalas; corola dialipétala ou com pétalas adnatas a base do tubo estaminal, 5 pétalas; estames com filetes livres, parcialmente ou totalmente concrescidos, 
formando tubo estaminal ou em um androginóforo; anteras monotecas e biesporangiadas ou ditecas e tetraesporangiadas; estaminódios presentes ou não; urcéolo membranáceo presente ou não; ovário súpero, 1-muitos lóculos, 1-muitos óvulos por lóculo; estiletes livres entre si ou parcialmente concrescidos, em número igual ou em dobro ao de carpelos, estigmas capitados, lobados ou penicilados. Frutos cápsulas, esquizocarpos ou núculas. Sementes 1-muitas; aladas ou não, glabras ou pubescentes.

Chave de identificação para as espécies de Malvaceae ocorrentes no Parque Estadual do Ibitipoca

1. Flores e frutos com epicálice

2. Estames concrescidos formando um tubo, estaminódios ausentes; sementes sem alas

3. Nectários extraflorais 1 ou 3 na base das nervuras centrais na face abaxial da lâmina; 5

estiletes; fruto cápsula

3. Hibiscus kitaibelifolius

3. Nectários extraflorais ausentes; 10 estiletes; fruto esquizocarpo

4. Inflorescências capituliformes; bractéolas do epicálice levemente espatuladas diferenciadas em haste e lâmina 7. Peltaea polymorpha

4. Flores solitárias; bractéolas do epicálice não diferenciadas em haste e lâmina

5. Presença de tricomas glandulares nas folhas; bractéolas do epicálice elípticas a lanceoladas

6. Pavonia viscosa

5. Ausência de tricomas glandulares nas folhas; bractéolas do epicálice obovadas a largo espatuladas 5. Pavonia sagittata

2. Estames agrupados em 5 falanges, estaminódios fimbriados; sementes aladas no ápice

3. Luehea grandiflora

1. Flores e frutos sem epicálice

6. Fruto esquizocarpo

7. Mericarpos com uma constrição formando 2 cavidades

20. Wissadula parviflora

7. Mericarpos sem constricção

8. Cálice não costado; 5-6 sementes por mericarpo .

1. Callianthe cf. elegans

8. Cálice costado; 1 semente por mericarpo

9. Ramos escandentes ou prostrados; esquizocarpo com 5 mericarpos

10. Ramos hirsutos; lâminas foliares 5-nervadas, base cordada

14. Sida urens

10. Ramos pubérulos; lâminas foliares 3-nervadas, base truncada

15. Sida viarum

9. Ramos eretos a decumbentes; esquizocarpos com 6 ou mais mericarpos

11. Lâminas foliares ciliadas; estípulas dimorfas, lineares, subfalcadas e/ou espatuladas

12. Arbusto ereto; ramos aplanados; folhas dísticas; esquizocarpo com 8 mericarpos aristados 12. Sida planicaulis

12. Subarbusto prostrado; ramos cilíndricos; folhas espiraladas; esquizocarpo com 6 mericarpos múticos 9. Sida harleyi

11. Lâminas foliares não ciliadas; estípulas iguais, lineares ou estreito triangulares

13. Estípulas 2-3-nervadas; brácteas bífidas; esquizocarpo com 10 ou 11 mericarpos 14. Ramos eretos; mericarpos com 2 aristas ca. $0,3 \mathrm{~cm}$ 10. Sida honoriana

14. Ramos decumbentes; mericarpos com 2 aristas ca. $0,1 \mathrm{~cm}$ 11. Sida lonchitis

13. Estípulas enervadas ou 1-nervada; brácteas bífidas ausentes; esquizocarpos com 9 mericarpos 15. Lâminas foliares 5-nervadas, face adaxial velutina; pétalas alvas com mácula basal vinácea; mericarpos múticos 8. Sida glaziovii

15. Lâminas foliares 3-nervadas, face adaxial pubescente; pétalas amarelas; mericarpos aristados 13. Sida rhombifolia

6. Fruto cápsula ou núcula

16. Estames 14-21; urcéolo membranáceo presente; frutos aculeados.

17. Subarbustos; estípulas lineares,enervadas; $14-15$ estames 17. Triumfetta rhomboidea 17. Arbustos; estípulas ovadas a lanceoladas com nervura na face abaxial; 20-21 estames 
18. Folhas irregularmente serreadas; androginóforo com 5 glândulas esféricas; fruto 0,4-0,5 cm, pubescente, 3-locular 18. Triumfetta semitriloba

18. Folhas serreadas; androginóforo com 5 glândulas elípticas; fruto 0,6-0,8 cm, glabrescentes, 7-8-locular..... 16. Triumfetta altheiodes

16. Estames 5-10; urcéolo membranáceo ausente; frutos sem acúleos

19. Subarbustos; estames formando tubo estaminal; estilete geniculado, estigma penicilado; cápsula obovóide, não espiralada 19. Waltheria indica

19. Arvoretas; estames em um androginóforo; estilete não geniculado, estigma capitado e papiloso; cápsula cilíndrica, espiralada

2. Helicteres brevispira

1. Callianthe cf. elegans (A.St.-Hil.) Donnell, Syst. Bot. 37: 719. 2012.

Figuras 2a-c, $4 \mathrm{a}-\mathrm{b}$

Arvoretas ou arbustos 3-4 m alt. Ramos cilíndricos, pubescentes a velutinos, tricomas estrelados, simples e glandulares. Folhas espiraladas; pecíolos 1,2-10,9 cm compr.; estípulas 0,4-0,7 cm compr., iguais entre si, lineares ou lanceoladas, 1-nervada; lâminas 2,3-14,3 × 1,7-10,2 cm, 7-nervadas, inteiras ou trilobadas, membranáceas, ovadas, discolores, ápice acuminado, base cordado-imbricada, margem crenado-serreada, ciliada, face adaxial pubescente, tricomas simples e glandulares amarelos, raro tricomas estrelados, face abaxial velutina, tricomas estrelados, simples e glandulares; nectários extraflorais ausentes. Inflorescência 1-2-flora, axilar; pedicelos 3,3-5,2 cm compr.; epicálice ausente; cálice cupuliforme, não costado, lobado abaixo da região mediana, sépalas 2,4-2,5 × 0,7-0,8 cm, lanceoladas, ápice acuminado, externamente tomentosas, tricomas estrelados, simples e glandulares; pétalas 2,4-2,6 × 1,5-1,6 cm, elípticas, alaranjadas com nervuras vináceas; estames mais de 50, tubo estaminal 1,2-1,3 cm compr., glabro, partes livres dos estames ca. 0,2 cm compr.; epicálice ausente; urcéolo membránaceo ausente; ovário 10 locular, 5-6 óvulos por lóculo, estiletes não geniculados, glabros, estigmas 10, capitados. Esquizocarpo, mericarpos 10, 2,4-2,5 × 1,5-1,6 cm, tomentosos, tricomas simples e estrelados; sementes 5-6, tricomas simples.

Material examinado: BRASIL. MinAs GERAIS: Lima Duarte, Distr. Conceição do Ibitipoca, Parque Estadual do Ibitipoca, Gruta dos Viajantes, 11-V-1970, fl., L. Krieger 8652 (CESJ, SP); ibid. 15-X-2009, fr., A.J. Fernandes-Júnior et al. 182 (CESJ); ibid., Pico do Pião, 11-V-1970, fl., fr., D. Sucre \& L. Krieger 6667 (RB); ibid., Cachoeirinha, 27-IX-2001, fr., L.C. Giordano et al. 2441 (RB); ibid., Lagoa Seca descendo para Cachoeirinha, 30-VI-2004, fl., E. von. S. Medeiros et al. 327 (RB). Ibid., 25-VII-2004, fl., fr., R.C. Forzza et al. 3500 (RB); ibid., 20-IX-2006, fl., F.M. Ferreira et al. 1141 (RB); ibid., Gruta dos Moreiras, 22-XII-2009, fl., A.J. Fernandes-Júnior et al. 190 (R).

Callianthe cf. elegans ocorre no Parque Estadual do Ibitipoca, Minas Gerais na Floresta Atlântica, na qual foi encontrada em mata ciliar e borda de mata.

Os espécimes foram identificados como Callianthe cf. elegans por apresentarem indumento formado por tricomas simples longos, glandulares e estrelados nos ramos e folhas, lâminas foliares com base cordada e imbricada, cálice tomentoso com base hirsuta, inflorescências 1-2-flora axilares, corola com pétalas alaranjadas com nervuras vináceas e fruto com 10 mericarpos. Dentre os caracteres supracitados, todos foram descritos por Saint-Hilaire (1828) na obra princeps de Abutilon elegans (= Callianthe elegans), exceto os caracteres do fruto, pois o material-tipo não apresenta frutos, apenas flores, porém a coloração das pétalas não foi descrita. Desta forma, a identificação precisa dos espécimes necessitará de mais estudos, pois a coloração das pétalas e os caracteres presentes nos frutos são imprescindíveis para a correta identificação das espécies do gênero Callianthe.

Callianthe cf. elegans assemelha-se a C. mouraei K. Schum. pelos caracteres vegetativos como indumento formado por tricomas simples longos, glandulares e estrelados nos ramos e folhas, lâminas foliares com base cordada, e reprodutivos pelas inflorescências 1-2-flora axilares e cálice tomentoso com base hirsuta. Entretanto, Callianthe cf. elegans possui corola com pétalas alaranjadas, com mácula basal esverdeada e nervuras vináceas (vs. rosadas a lilases, com mácula basal e nervuras lilases, mais escuras em $C$. mouraei) e fruto com 10 mericarpos sem papilas (vs. 12-15 mericarpos com papilas na sutura dorsal).

2. Helicteres brevispira A.St.-Hil., Fl. Bras. Merid. 1: 274, p1.54. 1828.

Figura 2d

Arvoretas ca. $5 \mathrm{~m}$ alt. Ramos cilíndricos, rugulosos, pubescentes, tricomas estrelados. Folhas 


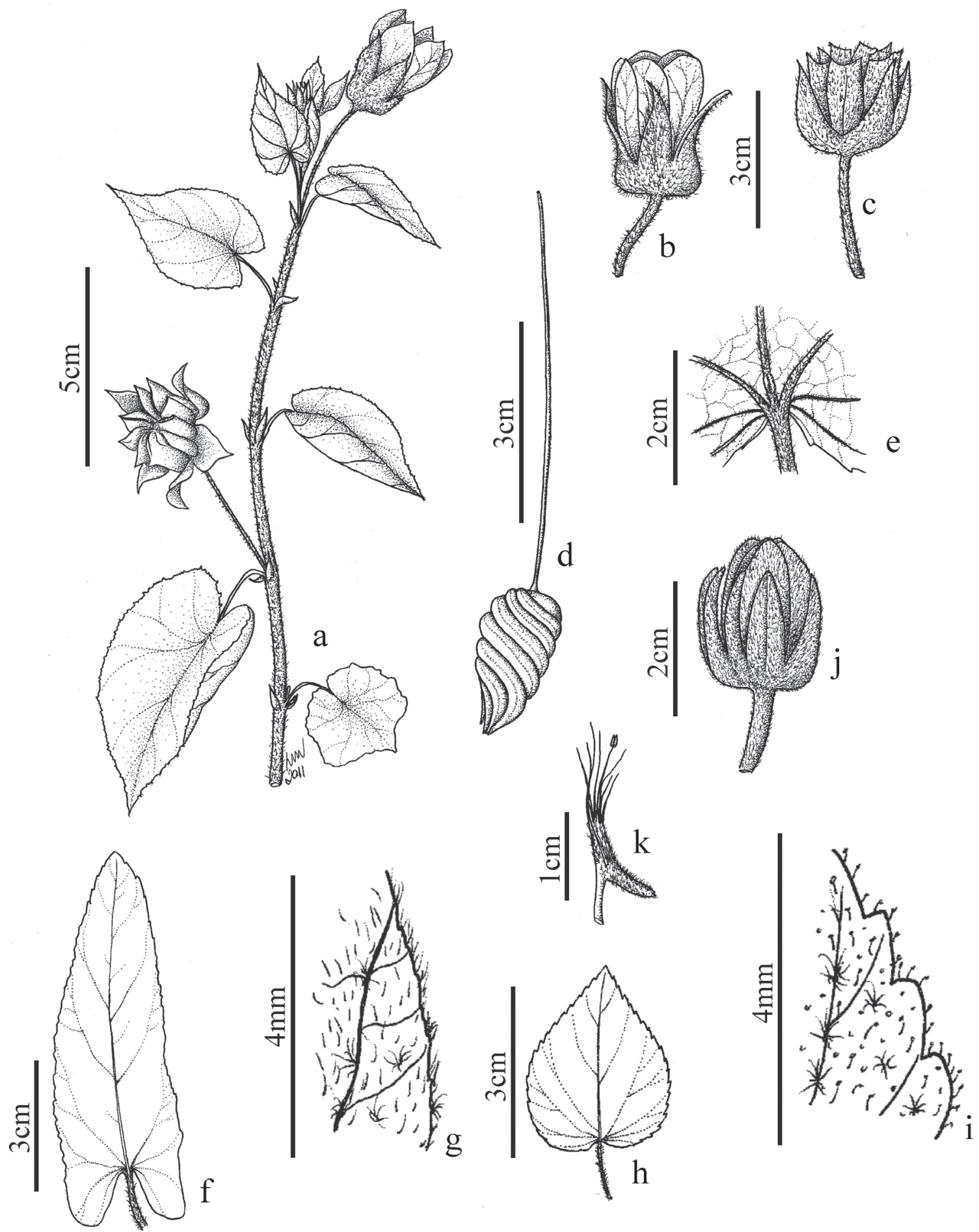

Figura 2. a-c. Callianthe cf. elegans. a. Ramo com flores e frutos. b. Flor. c. Fruto. Helicteres brevispira. d. Fruto. Hibiscus kitaibelifolius. e. Face abaxial da lâmina foliar, nectário na base da nervura central. f-g. Pavonia sagitatta. f. Folha, face adaxial. g. Margem da lâmina foliar, detalhe do indumento. h-i. Pavonia viscosa. h. Folha, face adaxial. i. Margem da lâmina foliar, detalhe do indumento. j-k. Luehea grandiflora. j. Botão floral com epicálice e cálice. k. Estaminódio.

Figure 2. a-c. Callianthe cf. elegans. a. Branch with flowers and fruits. b. Flower. c. Fruit. Helicteres brevispira. d. Fruit. Hibiscus kitaibelifolius. e. Abaxial surface of the leaf blade, nectary at the base of the midrib. f-g. Pavonia sagitatta. f. Leaf, adaxial surface. g. Margin of leaf blade, detail of the indumentum. h-i. Pavonia viscosa. h. Leaf, adaxial surface. i. Margin of leaf blade, detail of the indumentum. j-k. Luehea grandiflora. j. Floral bud with epicalyx and calyx. k. Staminode. 
espiraladas; pecíolos 1,8-2,4 cm compr.; estípulas 0,6-0,9 cm compr., iguais entre si, lineares, nervuras inconspícuas; lâminas 12,3-13,0 × 6,2-8,2 cm, 7-nervadas, inteiras, membranáceas, ovadas, concolores, ápice acuminado, base levemente cordada, margem irregularmente serreada, face adaxial pubescente, tricomas estrelados, face abaxial velutina, tricomas estrelados; nectários extraflorais ausentes. Inflorescência 2-flora, axilar; pedicelos 1,0-1,3 cm; epicálice ausente; cálice tubuloso, não costado, lobado na região apical, sépalas 1,7-1,8 ×0,5 cm, triangulares, ápice agudo, externamente tomentosas, tricomas estrelados; pétalas 2,7-4,5 ×0,9-1,3 cm, espatuladas, amareladas a alaranjadas; estames 10, androginóforo 9-9,5 cm compr., glabro, partes livres dos estames ca. 0,2 cm compr.; estaminódios presentes; urcéolo membránaceo ausente; ovário 5 locular, muitos óvulos por lóculo, estiletes não geniculados, tricomas estrelados, estigmas 5, capitados e papilosos. Cápsula 2,0-2,8 × 1,5 cm, cilíndrica, espiralada descrevendo um giro completo, pubescente, tricomas estrelados e simples; sementes muitas, glabras.

Material examinado: BRASIL. Minas Gerais: Lima Duarte, Distr. Conceição do Ibitipoca, Parque Estadual do Ibitipoca, divisa do PEIB com a Pedra do Gavião, 20-V-2005, fr., R.M. Castro et al. 397 (CESJ, RB).

Material adicional examinado: BRASIL. MINAS Gerais: Joaquim Felício, Serra do Cabral, s.d., fl., J.S. Silva 454 (SP); Delfinópolis, 24-II-2003, fl., J.N. Nakajima 3642 (SP).

Helicteres brevispira é uma das espécies de maior distribuição geográfica do gênero, estendendo-se desde a Colômbia e Venezuela, Paraguai e Brasil. No Brasil ocorre nos Estados de Rondônia, Tocantins, Maranhão, Piauí, Pernambuco, Bahia, Mato Grosso, Mato Grosso do Sul, Goiás, Distrito Federal, Minas Gerais, Espírito Santo, Rio de Janeiro, São Paulo e Paraná. A espécie é encontrada na Amazônia, Caatinga, Cerrado, Floresta Atlântica e Pantanal (Cristóbal 2001).

Em exemplares de herbário Helicteres brevispira pode ser facilmente confundida com os de $H$. ovata Lam., principalmente quando apresenta apenas frutos. Helicteres brevispira diferencia-se pelo hábito arborescente, inflorescência biflora e fruto espiralado descrevendo um giro, enquanto $H$. ovata arbusto escandente, inflorescência 6-7-floras e fruto espiralado descrevendo um giro e meio ou um giro e um quarto (Cristóbal 2001).
3. Hibiscus kitaibelifolius A. St.-Hil., Fl. Bras. Mer. 1: 248 , pl. 48.1828 .

Figuras 2e, 4c-d

Arbustos 2-3,5 m alt. Ramos cilíndricos, levemente aplanados nos ramos terminais, hirsutos, tricomas simples ca. $3 \mathrm{~mm}$ compr. e estrelados. Folhas espiraladas; pecíolos 0,8-5,3 cm compr.; estípulas $0,4-0,5 \mathrm{~cm}$ compr., iguais entre si, lanceoladas, 2-nervadas; lâminas 0,9-7,8 ×0,7-8,2 cm, (3-)5-7-nervadas, inteiras ou trilobadas, membranáceas a cartáceas, elípticas ou ovadas, discolores, ápice agudo ou acuminado, base redonda ou cordada, margem serreada, faces adaxial e abaxial pubescentes, tricomas estrelados; nectários extraflorais 1 ou 3, 2-3 mm, elípticos, na base das nervuras principais da face abaxial da lâmina. Inflorescência 1-2-flora, axilar ou terminal; pedicelos $0,8-3,1 \mathrm{~cm}$; epicálice formado por 12 bractéolas, 1,2-1,4 cm, filiformes, bifurcadas no ápice; cálice campanulado, não costado, lobado acima da região mediana, sépalas $2,5 \times 0,9 \mathrm{~cm}$, triangulares, ápice acuminado, externamente hirsutas, tricomas birradiados e estrelados, nectários elípticos; pétalas 5,4-5,7 × 3,7-4,6 cm, obdeltóides, rosadas com mácula basal purpúrea; estames mais de 50, tubo estaminal 2,8-3 cm compr., tricomas glandulares, partes livres dos estames ca. 0,1 cm compr.; epicálice ausente; urcéolo membránaceo ausente; ovário 5 locular, muitos óvulos por lóculo, estiletes não geniculados, tricomas glandulares e estrelados, estigmas 5, capitados. Cápsula 1,7-1,8 ×1,6 cm, glabra; sementes muitas, escamas pectinadas.

Material examinado: BRASIL. MinAs GeraIs: Lima Duarte, Distr. Conceição do Ibitipoca, Parque Estadual do Ibitipoca. Camping, 30-III-2004, fl., fr., R.C. Forzza et al. 3294 (RB); ibid., 30-VI-2004, fl., E. von S. Medeiros et al. 317 (RB); ibid., Mata do Centro de Pesquisa, 17-V-2006, fl., fr., R.C. Forzza et al. 4179 (RB); ibid., Campo rupestre do Centro de Pesquisa, 16-X-2009, fr., A.J. Fernandes-Júnior et al. 185 (CESJ); ibid., Campo rupestre do Centro de Pesquisa, 21-XII-2009, fl., A.J. Fernandes-Júnior et al. 187 (R).

Espécie endêmica do Brasil ocorrente no Sudeste de Minas Gerais e no Leste de São Paulo no Cerrado e Floresta Atlântica (Krapovickas \& Fryxell 2004).

Segundo Krapovickas \& Fryxell (2004), Hibiscus kitaibelifolius possui fruto glabro diferenciando-se de Hibiscus furcellatus Desr. no qual o fruto é hirsuto. H. kitaibelifolius e Hibiscus itirapinensis Krapov. \& Fryxell são os únicos da seção Furcaria na América do 
Sul que possuem três nectários constantes na base da nervura abaxial das folhas, enquanto as outras espécies variam de um a três, às vezes cinco. Nos espécimes coletados e observados no campo foi constatado que as folhas em crescimento apresentam somente um nectário.

4. Luehea grandiflora Mart., Nov. Gen. Sp. Pl.1: 99, t. 61.1826.

Figura $2 \mathrm{j}-\mathrm{k}$

Árvores ca. $5 \mathrm{~m}$ alt. Ramos cilíndricos, pubescentes a velutinos, tricomas estrelados. Folhas dísticas; pecíolos 1,1-1,2 cm compr.; estípulas ca. 0,4 cm compr., iguais entre si, lanceoladas, 2-nervadas; lâminas 9,1-15,5 × 3,9-9,9 cm, 5-nervadas, inteiras, coriáceas, oblongas ou ovadas, discolores, ápice agudo ou redondo, base irregular, margem irregularmente serreada, face adaxial pubérula, tricomas estrelados, face abaxial velutina com tricomas estrelados; nectários extraflorais ausentes. Inflorescência cimosa, multiflora axilar ou terminal; pedicelos 1,7-1,9 cm; epicálice formado por 8 bractéolas, 1,9-2,3 $\times$ 0,4-0,5 cm, lanceoladas, tomentosas; cálice campanulado, não costado, lobado abaixo da região mediana, sépalas 3,2-3,6 × 0,9-1,1 cm, lanceoladas, ápice agudo a acuminado, externamente tomentosas, tricomas simples e bífidos; pétalas ca. $2,7 \times 1,1 \mathrm{~cm}$, lanceoladas a espatuladas, alvas; estames ca. 100 agrupados em 5 falanges, ca. 0,5 cm compr., tricomas simples, partes livres dos estames 1,4-1,6 cm compr.; estaminódios curtamente fimbriados; urcéolo membránaceo ausente; ovário 5 locular, muitos óvulos por lóculo, estiletes não geniculados, glabros, estigma capitado, 5-lobado. Cápsula 1,5-2,0 ×0,7-1 cm, pentagonal, deiscente até a região mediana, tricomas simples; sementes muitas, aladas no ápice, glabras.

Material examinado: BRASIL. Minas Gerais: Lima Duarte, Distr. Conceição do Ibitipoca, Parque Estadual do Ibitipoca. 22-VI-2001, fl., F.S. Araújo \& L.C.S. Assis 146 (CESJ, RB).

Material adicional examinado: BRASIL. MINAS GeraIS: Juiz de Fora, VIII-1969, fr., L. Krieger s.n. (RB 492046); Guarani, 11-X-1997, fr., A. Salino $3542(\mathrm{RB})$.

Ocorre nos Estados do Pará, Maranhão, Ceará, Bahia, Mato Grosso, Mato Grosso do Sul, Distrito Federal, Minas Gerais, Rio de Janeiro, São Paulo e Paraná. A espécie é encontrada na Amazônia, Caatinga, Cerrado, Floresta Atlântica e Pantanal (Cunha 1985).
Luehea grandiflora é uma espécie muito próxima de Luehea speciosa Willd. e ambas tem o mesmo aspecto geral e morfologia semelhante, o que faz com que geralmente sejam confundidas. As duas são bastante polimorfas, e a grande diferença entre elas está nos estaminódios que, em Luehea speciosa se apresentam profundamente fimbriados e em Luehea grandiflora são apenas sutilmente fimbriados. Apesar das duas espécies serem próximas, Luehea speciosa não ocorre no Brasil (Cunha 1985).

Em exemplares de herbário, Luehea grandiflora pode ser encontrada erroneamente identificada como Luehea divaricata Mart. que possui pétalas suborbiculares à rombeo-obovadas, estames com falanges unidas na base formando um anel e estaminódios fimbriados até a metade apical, enquanto Luehea grandiflora possui pétalas lanceoladas a espatuladas, estames com falanges não formando anel e estaminódios sutilmente fimbriados (Cunha 1985).

5. Pavonia sagittata A. St.-Hil., Fl. Bras. Mer., 1: 229. 1828.

Figura 2f-g, $4 \mathrm{~g}$

Arbustos 0,6-0,8 m alt. Ramos cilíndricos, tomentosos, tricomas estrelados amarelados. Folhas espiraladas; pecíolos 0,5-1,5 cm compr.; estípulas $0,3 \mathrm{~cm}$ compr., iguais entre si, lineares, nervuras inconspícuas; lâminas 1,5-9,2 × 0,9-2,9 cm, 7(-8)-nervadas, sagitadas, membranáceas, lanceoladas ou oblongas, discolores, ápice agudo ou obtuso, base sagitada a cordada, margem crenada-serreada, face adaxial pubescentes, tricomas estrelados, face abaxial velutina, tricomas estrelados; nectários extraflorais ausentes. Flores solitárias, axilares; pedicelos 1,8-2,4 cm; epicálice formado por 5-6-bractéolas, $0,4-0,6 \times 0,3-0,5 \mathrm{~cm}$, obovadas a largo espatuladas, tomentosas, tricomas estrelados; cálice campanulado, não costado, lobado acima da região mediana, sépalas 0,6 $\times 0,5 \mathrm{~cm}$, triangulares, ápice agudo, externamente tomentosa, tricomas estrelados; pétalas 1,4-2 × 1,1-1,5 cm, obovadas, rosadas; estames 20-30, tubo estaminal 0,6-0,8 cm compr., glabro, partes livres dos estames ca. 0,1 cm compr.; epicálice ausente; urcéolo membránaceo ausente; ovário 10 locular, um óvulo por lóculo, estiletes não geniculados, glabros, estigmas 10, capitados. Esquizocarpo, mericarpos 5, ca. $0,4 \times 0,3 \mathrm{~cm}$, levemente nervados, glabros; semente única, tricomas simples.

Material examinado: BRASIL. MinAs Gerais: Lima Duarte, Distr. Conceição do Ibitipoca, Parque Estadual 
do Ibitipoca, caminho próximo à portaria do PEIB, 14-X-2009, fr., A.J. Fernandes-Júnior \& D.B.C. Puida 181 (CESJ).

Espécie endêmica do Brasil. Ocorre nos Estados da Bahia, Goiás, Distrito Federal, Minas Gerais, Mato Grosso do Sul, São Paulo e no Rio Grande do Sul. A espécie é encontrada no Cerrado e Floresta Atlântica (Fryxell 1999).

Pavonia sagittata é uma espécie próxima de $P$. hastata Cav., diferenciando-se pela forma das bractéolas do epicálice e indumento dos ramos. Pavonia sagittata caracteriza-se por apresentar indumento amarelo forte, pelas bractéolas do epicálice muito largas, variando de obovada-espatulada até quase orbiculares e pela nervação muito leve dos mericarpos, enquanto $P$. hastata apresenta indumento glauco, bractéolas do epicálice elípticas a estreitamente obovadas e mericarpos com nervação leve a proeminente, sem ou com 2-4 tubérculos em cada lado da nervura média (Fryxell 1999).

6. Pavonia viscosa A. St.-Hil., Fl. Bras. Mer. 1: 236. 1828.

Figura 2 h-i, 4e-f

Arbustos 2-3 m alt. Ramos cilíndricos, rugulosos e glabrescentes, tricomas glandulares. Folhas espiraladas; pecíolos 0,2-2,1 cm compr.; estípulas $0,3 \mathrm{~cm}$ compr., iguais entre si, lineares, 1-nervada; lâminas 0,6-3,2 × 0,3-3,1 cm, 7-9-nervadas, inteiras ou trilobadas, membranáceas, ovadas, lanceoladas, discolores, ápice agudo ou acuminado, base arredondada ou cordada, margem serreada e ciliada, faces adaxial e abaxial pubérulas, tricomas glandulares, estrelados e simples; nectários extraflorais ausentes. Flores solitárias, axilares; pedicelos 2,4-2,9 cm; epicálice formado por 15 bractéolas, 1,3-1,4 $\times 0,1 \mathrm{~cm}$, elípticas com ápice agudo, pubescentes, tricomas simples e glandulares; cálice tubuloso, não costado, sépalas 1,2-1,3 ×0,5 cm, triangulares, ápice agudo, externamente tomentosas, tricomas simples e glandulares; pétalas ca. $2,4 \times 0,8 \mathrm{~cm}$, obelíptica, alaranjadas e amarelo-esverdeadas com guias de néctar vináceos; estames mais de 30 , tubo estaminal 1,6-1,8 cm compr., tricomas estrelados na porção basal, partes livres dos estames 0,3-0,5 cm compr.; epicálice ausente; urcéolo membránaceo ausente; ovário 5 locular, um óvulo por lóculo, estiletes não geniculados, tricomas glandulares, estigmas 10, capitados. Esquizocarpo, mericarpos 5, ca. $0,7 \times 0,5 \mathrm{~cm}$, glabros; semente única, glabra.
Material examinado: BRASIL. Minas GeraIs: Lima Duarte, Distr. Conceição do Ibitipoca, Parque Estadual do Ibitipoca, Pico do Pião, 14-V-1970, fl., D. Sucre \& L. Krieger 6834 (RB); ibid., Rio do Salto, Lago das Miragens, 21-XII-2009, fl., fr., A.J. FernandesJúnior et al. 188 (R); ibid., 21-XII-2009, fl., fr., A.J. Fernandes-Júnior et al. 189 (R); ibid., 8-V-2002, fl., fr., L.C. Giodano et al. 2467 (RB). ibid., caminho para Ponte de Pedra, 8-V-2002, fl., R. Marquete et al. 3212 (RB); ibid., 1-XII-2004, fl., E. von S. Medeiros et al. 390 (RB); ibid., Rio do Salto, 9-III-2004, fl., R.C. Forzza et al. 3030 (RB); ibid., 21-I-2005 (fl.), R.C. Forzza et al. 3972 (RB).

Espécie endêmica do Brasil ocorrente no Estado de Minas Gerais na Cadeia do Espinhaço no Cerrado (Fryxell 1999).

Pavonia viscosa é uma espécie próxima de $P$. montana Garcke ex Gürke e P. malvaviscoides A.St.-Hil. Pavonia viscosa caracteriza-se pelo indumento constituído predominantemente por tricomas glandulares e pelo epicálice composto de bractéolas elípticas, além disto, destaca-se sua forte viscosidade, dada a grande quantidade de tricomas glandulares que reveste toda a planta. $P$. montana apresenta tricomas simples predominantemente e bractéolas do epicálice filiformes longamente ciliadas menores que o cálice, enquanto $P$. malvaviscoides apresenta indumento levemente incano com tricomas estrelados e bractéolas do epicálice linear-subuladas (Fryxell 1999).

7. Peltaea polymorpha (A.St.-Hil.) Krapov. \& Cristóbal, Kurtziana 2:199. 1965.

Figura $4 h-j$

Subarbustos 0,3-0,4 m alt.; xilopódio presente. Ramos decumbentes, cilíndricos, pubescentes, tricomas estrelados. Folhas espiraladas; pecíolos 0,3-0,8 cm compr.; estípulas 0,2-0,3 cm compr., iguais entre si, lineares, 1-nervada; lâminas 2,3-5,4 × 1,5-3,2 cm, 5-(7-)-nervadas, inteiras, membranáceas a cartáceas, elípticas ou ovadas, discolores, ápice agudo ou acuminado, base arredondada ou truncada, margem crenada-serreada,f aces adaxial e abaxial pubescentes, tricomas estrelados; nectários extraflorais ausentes. Inflorescência capituliforme, terminal, flores na axila de brácteas foliáceas; pedicelos ca. $0,1 \mathrm{~cm}$; epicálice formado por 10 bractéolas espatuladas divididas em pé 0,5-0,6 cm compr., e lâmina $0,2-0,3 \times 0,1$, hirsutas, tricomas simples e estrelados; cálice campanulado, não costado, lobado até a região mediana, sépalas 
$0,5 \times 0,3 \mathrm{~cm}$, lanceoladas, ápice agudo, externamente tomentosas, tricomas estrelados; pétalas $3,4 \times 2,9 \mathrm{~cm}$, obovadas, rosadas com mácula basal vinácea; estames 19-22, tubo estaminal 0,9-1 cm compr., tricomas glandulares, partes livres dos estames ca. $0,2 \mathrm{~cm}$ compr.; epicálice ausente; urcéolo membránaceo ausente; ovário 5 locular, um óvulo por lóculo, estiletes não geniculados, tricomas glandulares, estigmas 10, capitados. Esquizocarpo, 5 mericarpos ca. $0,4 \times 0,2 \mathrm{~cm}$, pubescentes, tricomas estrelados; semente única, tricomas simples.

Material examinado: BRASIL. MinAs GeraIs: Lima Duarte, Distr. Conceição do Ibitipoca, Parque Estadual do Ibitipoca, 25-XI-2004, fl., fr., B. Chiavegatto et al. 127 (RB); ibid., caminho para Cruzeiro após Gruta das Bromélias, 20-I-2010, fr., A.J. Fernandes-Júnior \& J.E. Assis-Júnior 202 (R); ibid., 30-XI-2004, fl., fr., E. von S. Medeiros et al. 355 (RB); ibid., trilha Monjolinho-Lagoa Seca, 18-I-2005, fl., fr., R.C. Forzza et al. 3916 (RB).

Espécie endêmica do Brasil, encontrada predominantemente no Cerrado, mas também na Floresta Atlântica. Ocorre nos Estados de Mato Grosso, Goiás, Minas Gerais, São Paulo, Paraná e Santa Catarina (Krapovickas \& Cristóbal 1965).

Peltaea polymorpha caracteriza-se pelo hábito subarbustivo decumbente, flores subsésseis agrupadas no ápice dos ramos formando inflorescências capituliformes na axila de brácteas foliáceas, raramente flores solitárias e mericarpos deiscentes e pubescentes (Fernandes-Júnior 2016).

Morfologicamente é uma espécie próxima a Peltaea macedoi Krapov. \& Cristóbal, que se diferencia por apresentar a face abaxial velutina e incana, além das brácteas foliáceas com mácula basal vinácea (Fernandes-Júnior 2016).

8. Sida glaziovii K.Schum., Fl. Bras. 12: 322. 1891. Figuras 3a, 4k

Subarbustos 0,3-0,4 m alt. Ramos decumbentes, cilíndricos, tomentosos, estrelados e simples. Folhas espiraladas; pecíolos 0,2-0,7 cm compr.; estípulas 0,4-0,9 cm compr., iguais entre si, lineares, nervuras inconspícuas; lâminas 0,5-4,3 ×0,4-2,4 cm, 5-nervadas, inteiras, membranáceas a cartáceas, obovadas ou rômbicas, discolores, ápice agudo ou redondo, base obtusa ou redonda, margem serreada $2 / 3$ apicais, faces adaxial e abaxial velutinas, tricomas estrelados; nectários extraflorais ausentes. Inflorescência cimosa em glomérulos ou flores solitárias, axilares; pedicelos 1-1,2 cm; epicálice ausente; cálice campanulado, costado, lobado até região mediana, sépalas $0,7 \times 0,4 \mathrm{~cm}$, triangulares, ápice agudo, externamente tomentosas, tricomas estrelados; pétalas ca. $0,8 \times 0,6 \mathrm{~cm}$, obovadas, alvas a creme com mácula vinácea; estames 22 , tubo estaminal ca. 0,1 cm compr., tricomas glandulares, partes livres dos estames ca. 0,1 cm compr.; epicálice ausente; urcéolo membránaceo ausente; ovário 9 locular, um óvulo por lóculo, estiletes não geniculados, glabros, estigmas 9, capitados. Esquizocarpo, mericarpos 9, ca. $0,3 \times 0,2 \mathrm{~cm}$, múticos, pubescentes, tricomas simples e estrelados; semente única, tricomas simples.

Material examinado: BRASIL. Minas Gerais: Lima Duarte, Distr. Conceição do Ibitipoca, Parque Estadual do Ibitipoca, Centro de Pesquisa, 20-I-2010, fl., A.J. Fernandes-Júnior \& J.E. Assis-Júnior 201 (R); ibid., 23-IV-2010, fr., A.J. Fernandes-Júnior \& M.G. Bovini 218 (CESJ).

Espécie endêmica do Brasil. Ocorre nos Estados do Mato Grosso do Sul, Distrito Federal, Minas Gerais, Espírito Santo, Rio de Janeiro, São Paulo e Paraná, no Cerrado e na Floresta Atlântica (Bovini et al. 2016).

Sida glaziovii caracteriza-se por apresentar folhas rombiformes ou obovadas, indumento verde claro nas folhas e ramos e corola alva a creme com mácula basal vinácea (Bovini et al. 2001).

9. Sida harleyi Krapov., Bonplandia 16: 239-240. 2007.

Figura $3 b$

Subarbustos prostrados. Ramos prostrados, cilíndricos, pubescentes, tricomas estrelados. Folhas espiraladas; pecíolos 0,3-1,6 cm compr.; estípulas 0,2-0,4 cm compr., dimorfas, uma linear e a outra espatulada, nervuras inconspícuas; lâminas 0,8-5,0 × 0,6-2,5 cm, 5-7(-8)-nervadas, inteiras, membranáceas a cartáceas, obovadas, discolores, ápice obtuso, base truncada, margem crenada-serreada $2 / 3$ apicais, ciliada, face adaxial pubescente, tricomas simples e estrelados, face abaxial pubescentes, tricomas estrelados; nectários extraflorais ausentes. Inflorescência cimosa em glomérulos, terminais, raramente flores solitárias; pedicelos $0,2-0,3 \mathrm{~cm}$; epicálice ausente; cálice campanulado, costado, lobado até região mediana, sépalas ca. $0,7 \times 0,4 \mathrm{~cm}$, triangulares, ápice agudo, externamente hirsutas, tricomas estrelados e simples; pétalas ca. $0,7 \times 0,6 \mathrm{~cm}$, obdeltóides, amarelas; estames 22 , tubo estaminal 

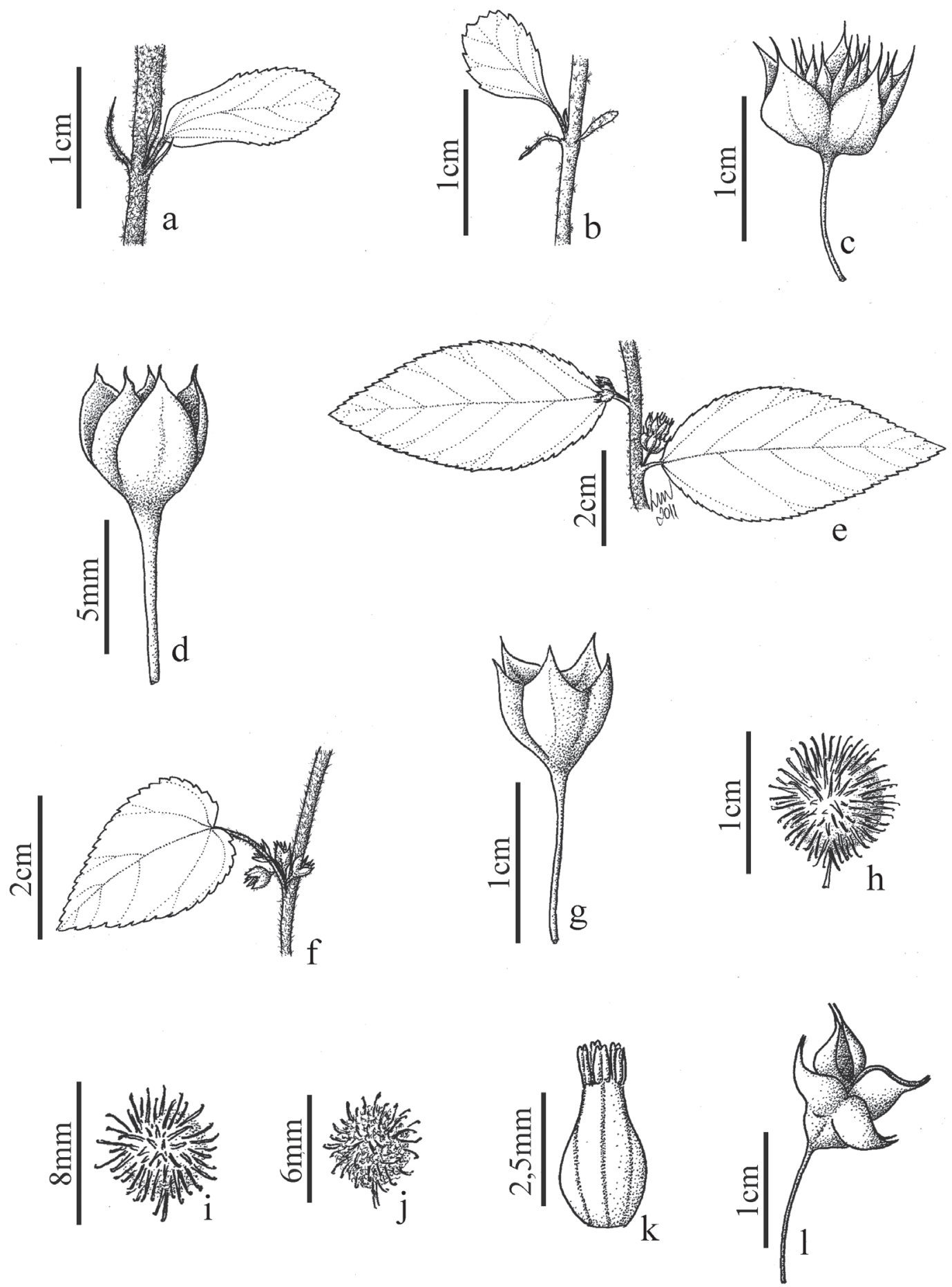

Figura 3. Sida glaziovii. a. Ramo, detalhe das estípulas. Sida harleyi. b. Ramo, detalhe das estípulas dimorfas. Sida honoriana. c. Fruto evidenciando as aristas e recoberto pelo cálice. Sida lonchitis. d. Cálice. Sida planicaulis. e. Ramo com inflorescência. Sida urens. f. Ramo com inflorescência. Sida viarum. g. Cálice. Triumfetta altheioides. h. Fruto. Triumfetta semitriloba. i. Fruto. Triumfetta rhomboidea. j. fruto. Waltheria indica. k. Tubo estaminal. Wissadula parviflora. 1. Fruto.

Figure 3. Sida glaziovii. a. Branch, detail of the stipules. Sida harleyi. b. Branch, detail of the dimorphic stipules. Sida honoriana. c. Fruit evidencing the awns and covered by the calyx. Sida lonchitis. d. Calyx. Sida planicaulis. e. Inflorescence branch. Sida urens. f. Inflorescence branch. Sida viarum. g. Calyx. Triumfetta altheioides. h. Fruit. Triumfetta semitriloba. i. Fruit. Triumfetta rhomboidea. j. Fruit. Waltheria indica. k. Staminal tube. Wissadula parviflora. 1. Fruit. 

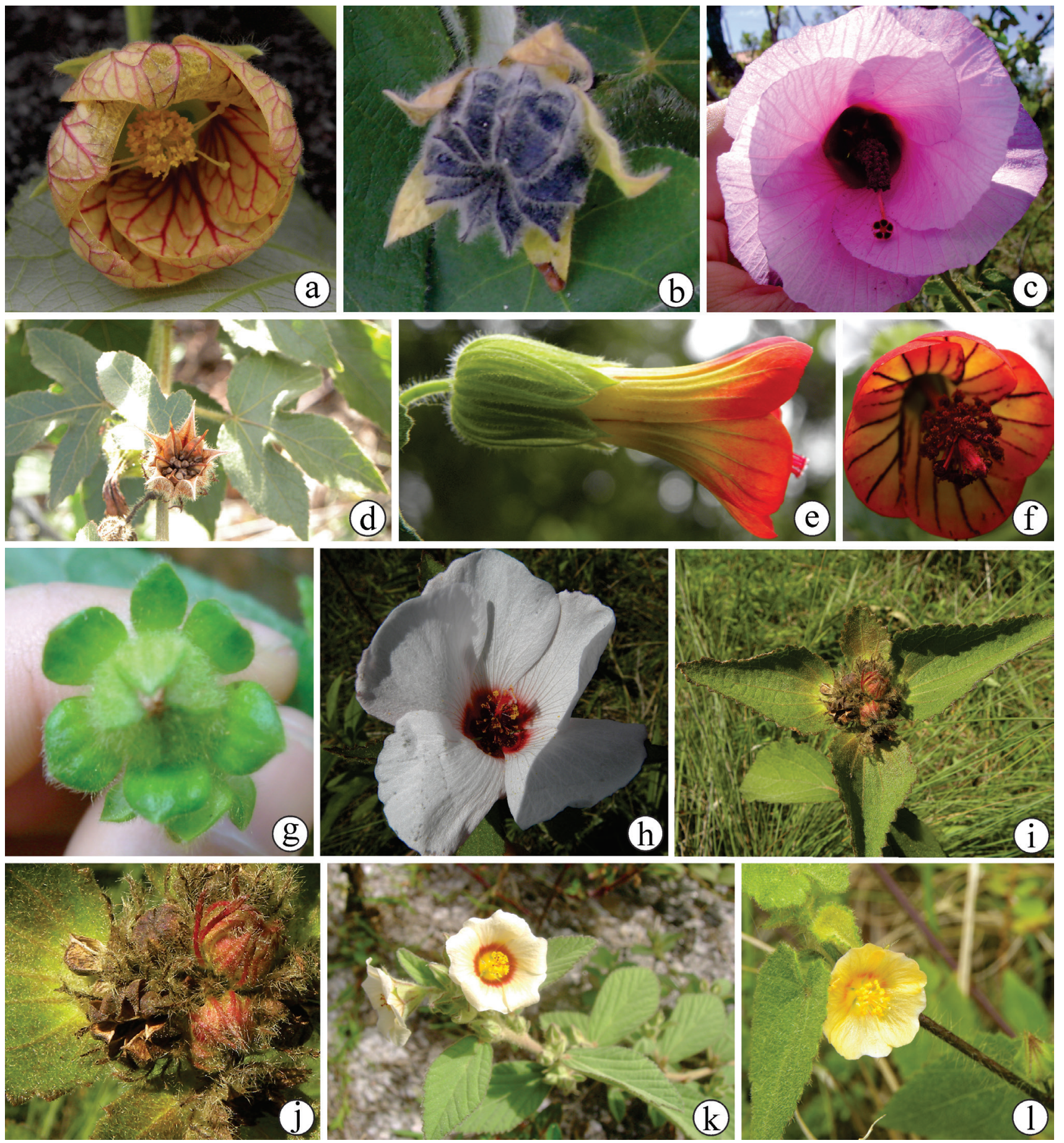

Figura 4. a-b. Callianthe cf. elegans. a. Flor. b. Fruto. c-d. Hibiscus kitaibelifolius. c. Flor. d. Ramo com frutos. e-f. Pavonia viscosa. e. Flor, vista lateral. f. Flor, vista frontal. Pavonia sagitatta. g. Botão floral, vista frontal, detalhe das bractéolas. h-i. Peltaea polymorpha. h. Flor, vista frontal. i. Ramo com frutos e brácteas foliáceas. j. Frutos indeiscentes. Sida glaziovii. k. Ramo com flor. Sida urens. 1. Ramo com flor. (Fotos: A.J. Fernandes-Júnior).

Figure 4. a-b. Callianthe cf. elegans. a. Flower. b. Fruit. c-d. Hibiscus kitaibelifolius. c. Flower. d. Branch with fruits. e-f. Pavonia viscosa. e. Flower, lateral view. f. Flower, frontal view. Pavonia sagitatta. g. Floral bud, frontal view, detail of the bracteoles. h-i. Peltaea polymorpha. h. Flower, frontal view. i. Branch with fruits and foliaceous bracts. j. Indehiscent fruits. Sida glaziovii. k. Branch with flower. Sida urens. 1. Branch with flower. (Photos: A.J. Fernandes-Júnior). 
ca. 0,1 cm compr., tricomas simples, partes livres dos estames ca. 0,1 cm compr.; epicálice ausente; urcéolo membránaceo ausente; ovário 6 locular, um óvulo por lóculo, estiletes não geniculados, glabros, estigmas 6, capitados. Esquizocarpo, mericarpos 6 , ca. $0,2 \times 0,2 \mathrm{~cm}$, múticos, glabrescentes a pubescentes, tricomas estrelados; semente única, tricomas estrelados.

Material examinado: BRASIL. Minas Gerais: Lima Duarte, Distr. Conceição do Ibitipoca, Parque Estadual do Ibitipoca, 16-IX-1970, fl., D. Sucre 7098 (RB); ibid., campo rupestre próximo a portaria do PEIB, 30-III-2011, fl., fr., A.J. Fernandes-Júnior 254 (CESJ).

Espécie endêmica do Brasil ocorre nos Estados da Bahia e Minas Gerais no Cerrado e na Floresta Atlântica (Krapovickas 2007).

A espécie caracteriza-se por apresentar estípulas dimorfas, uma linear outra espatulada, pétalas amarelas e 6-8 mericarpos múticos (Krapovickas 2007). Sida harleyi foi encontrada apenas próximo a portaria do PEIB com poucos indivíduos.

10. Sida honoriana Krapov., Bonplandia 16(3-4):194. 2007.

Figuras 3c, 5a-c

Arbustos 0,7-2 m alt. Ramos cilíndricos, levemente aplanados nos Ramos laterais, pubescentes, tricomas estrelados e simples. Folhas espiraladas; pecíolos 0,5-1,1 cm compr.; estípulas 0,3-0,7 cm compr., iguais entre si, lineares, 2-3-nervadas; lâminas 1-6,9 ×0,3-3 cm, 5-nervadas, inteiras, cartáceas, rombiformes, elípticas a lanceoladas, discolores, ápice agudo, base redonda ou truncada, margem serreada $2 / 3$ apicais, face adaxial pubescente, tricomas estrelados, face abaxial velutina, tricomas estrelados e simples; nectários extraflorais ausentes. Flores solitárias, axilares, flores na axila de brácteas bífidas; pedicelos 0,9-1,4 cm; epicálice ausente; cálice campanulado, costado, lobado no 1/3 superior, sépalas 0,6-0,7 $\times 0,4 \mathrm{~cm}$, triangulares, ápice acuminado, externamente pubérulas, tricomas estrelados; pétalas ca. $0,8 \times 0,5 \mathrm{~cm}$, obovadas, amarelas; estames 24 , tubo estaminal ca. 0,2 cm compr., tricomas glandulares, partes livres dos estames ca. 0,1 cm compr.; epicálice ausente; urcéolo membránaceo ausente; ovário 10 locular, um óvulo por lóculo, estiletes não geniculados, glabros, estigmas 10, capitados. Esquizocarpo, mericarpos $10,0,3 \times 0,2 \mathrm{~cm}$, com 2 aristas de ca. 0,3 cm compr., pubescentes, tricomas estrelados; semente única, tricomas estrelados.
Material examinado: BRASIL. Minas GeraIs: Lima Duarte, Distr. Conceição do Ibitipoca, Parque Estadual do Ibitipoca, em frente a administração do PEIB, 23-XII-2009, fr., A.J. Fernandes-Júnior et al. 193 (R); ibid., 20-II-2010, fl., A.J. Fernandes-Júnior \& A.L. Santiago 208 (CESJ).

No Brasil, nos Estados de Minas Gerais, São Paulo, Rio de Janeiro, Paraná e no Distrito Federal, no Cerrado e Floresta Atlântica (Bovini et al. 2016).

Sida honoriana é erroneamente confundida com S. rhombifolia por apresentarem em comum as lâminas rombiformes. A espécie caracteriza-se por apresentar as flores na base de brácteas bífidas e mericarpos aristados, sendo que as aristas são do mesmo tamanho do mericarpo (Krapovickas 2007).

11. Sida lonchitis A.St.-Hil. \& Naudin, Ann. Sci. Nat., Bot. sér. 2, 18: 50. 1842.

Figuras 3d, 5d-f

Subarbustos ca. 0,4 m alt. Ramos decumbentes, cilíndricos, pubescentes, tricomas estrelados. Folhas espiraladas; pecíolos 0,3-0,5 cm compr.; estípulas 0,4-0,7 cm compr., iguais entre si, estreitotriangulares, ápice acuminado, 3-nervadas; lâminas 0,8-3,5 × 0,3-1,2 cm, 3-nervadas, inteiras, cartáceas, elípticas, oblongas ou rômbica, discolores, ápice agudo ou acuminado, base redonda ou truncada, margem serreada 2/3 apicais, face adaxial pubérula, tricomas estrelados e simples, face abaxial pubérula, tricomas estrelados; nectários extraflorais ausentes. Inflorescência corimbo, terminal, flores na axila de brácteas bífidas; pedicelos ca. $0,3 \mathrm{~cm}$; epicálice ausente; cálice campanulado, costado, lobado na região mediana, sépalas ca. $0,7 \times 0,4 \mathrm{~cm}$, triangulares, ápice acuminado, externamente pubérulas, tricomas simples, estrelados e glandulares; pétalas ca. $0,6 \times 0,5 \mathrm{~cm}$, obovadas, amarelas; estames 20, tubo estaminal ca. 0,1 cm compr., tricomas glandulares, partes livres dos estames ca. 0,05 cm compr.; epicálice ausente; urcéolo membránaceo ausente; ovário 10-11 locular, um óvulo por lóculo, estiletes não geniculados, glabros, estigmas 10-11, capitados. Esquizocarpo, mericarpos 10-11, 0,3 $\times 0,3 \mathrm{~cm}$, com 2 aristas de ca. 0,1 cm compr., glabrescentes, tricomas estrelados; semente única, glabra.

Material examinado: BRASIL. MinAs GeraIs: Lima Duarte, Distr. Conceição do Ibitipoca, Parque Estadual do Ibitipoca, campo rupestre ao lado do restaurante, 20-II-2010, fl., fr., A.J. Fernandes-Júnior \& A.L. Santiago 207 (CESJ). 

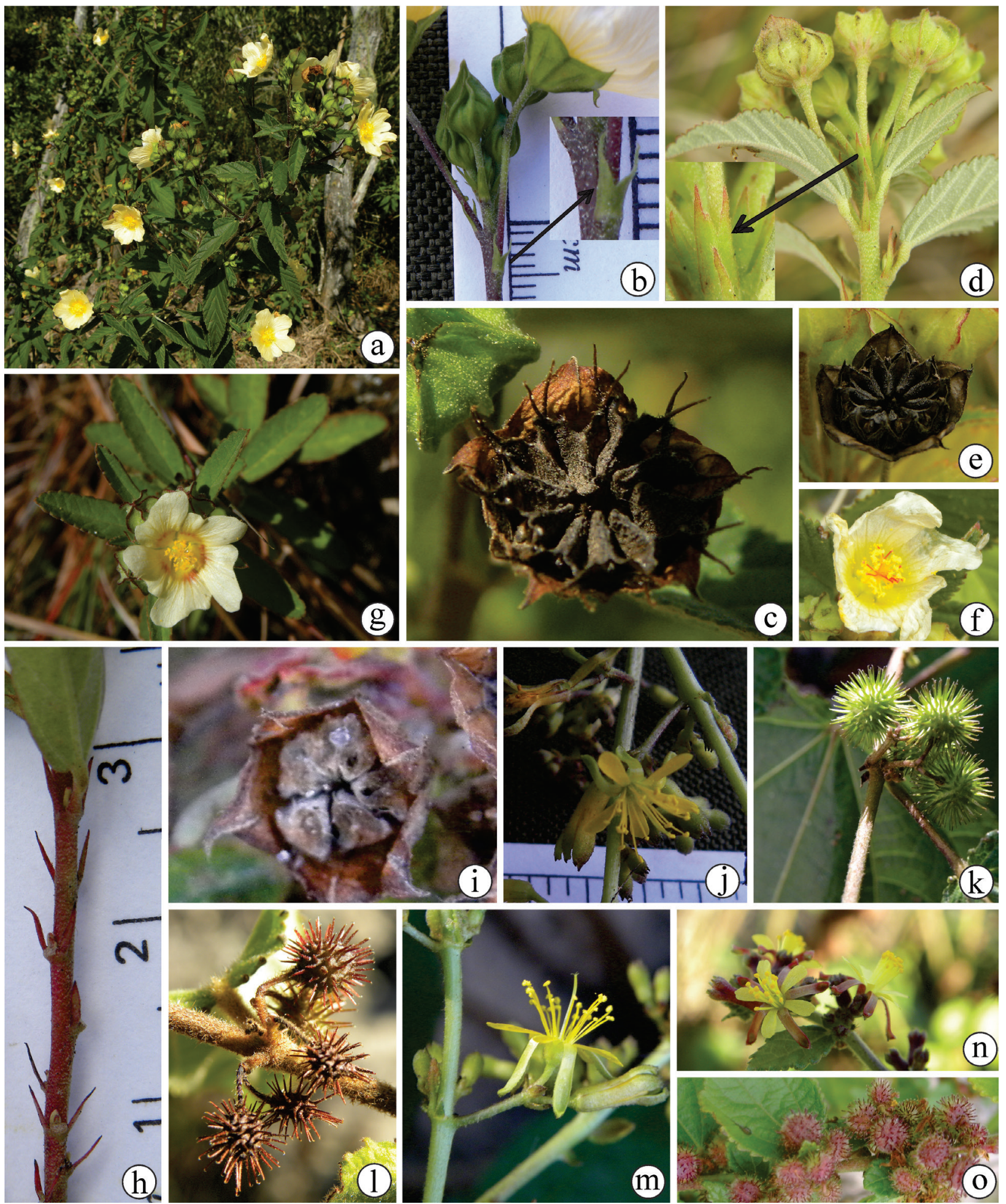

Figura 5. a-c. Sida honoriana. a. Hábito. b. Inflorescência, detalhe da bráctea bifurcada. c. Frutos. d-f. Sida lonchitis. d. Inflorescência, detalhe da bráctea bifurcada. e. Fruto. f. Flor. g-i. Sida viarum. g. Hábito. h. Ramo com estípulas persistentes. i. Fruto. j-k. Triumfetta altheioides. j. Flor. k. Frutos. 1-m. Triumfetta semitriloba. 1. Frutos. m. Flor. n-o. Triumfetta rhomboidea. n. Flores. o. Frutos. (Fotos: A.J. Fernandes Júnior).

Figure 5. a-c. Sida honoriana. a. Habit. b. Inflorescence, detail of the bifurcate bract. c. Fruits. d-e. Sida lonchitis. d. Inflorescence, detail of the bifurcate bract. e. Fruit. f. Flower. g-i. Sida viarum. g. Habit. h. Branch with persistent stipules. i. Fruit. j-k. Triumfetta altheioides. j. Flower. k. Fruit. 1-m. Triumfetta semitriloba. 1. fruits. m. Flower. n-o. Triumfetta rhomboidea. n. Flowers. o. Fruits. (Photos: A.J. Fernandes-Júnior). 
Espécie endêmica do Brasil ocorre nos Estados de Minas Gerais, Rio de Janeiro, São Paulo, Distrito Federal, Paraná e Santa Catarina, no Cerrado e Floresta Atlântica (Krapovickas 2007).

Sida lonchitis caracteriza-se pelas flores agrupadas no ápice dos ramos e brácteas bífidas na base das flores. Segundo Krapovickas (2007), esta espécie é geralmente encontrada nos herbários como Sida rhombifolia L., podendo ser diferenciada pela bráctea bífida.

\section{Sida planicaulis Cav., Monadelphiae Classis}

Dissertationes Decem 1: 24, pl. 3. 1785.

Figura 3d

Subarbustos 0,3-0,4 m alt. Ramos eretos, cilíndricos, aplanados nos ramos terminais, glabrescentes, tricomas estrelados. Folhas dísticas, pecíolos 0,3-0,6 cm compr.; estípulas 0,6-0,7 cm compr., dimorfas, uma subfalcada e a outra linear, 3-nervadas; lâminas 1,8-7,9 × 1,0-3,3 cm, 3-nervadas, inteiras, membranáceas a cartáceas, elípticas ou lanceoladas, levemente discolores, ápice agudo, base arredondada ou oblíqua, margem serreada, ciliada, face adaxial glabrescente, tricomas simples, face abaxial pubérula, tricomas simples; nectários extraflorais ausentes. Inflorescência cimosa em glomérulos ou flores solitárias, axilares; pedicelos 0,1-0,2 cm; epicálice ausente; cálice campanulado, costado, lobado até região mediana, sépalas ca. 0,6 ×0,4 cm, triangulares, ápice agudo, pubescentes; pétalas ca. $0,6 \times 0,4 \mathrm{~cm}$, obovadas, amarelas; estames 20 , tubo estaminal ca. 0,1 cm compr., glabros, partes livres dos estames ca. 0,1 cm compr.; epicálice ausente; urcéolo membránaceo ausente; ovário 8 locular, um óvulo por lóculo, estiletes não geniculados, glabros, estigmas 8, capitados. Esquizocarpo, mericarpos 8, $0,2 \times 0,2 \mathrm{~cm}$, com 2 aristas de ca. 0,2 cm compr., glabrescentes, tricomas estrelados; semente única, tricomas estrelados.

Material examinado: BRASIL. Minas Gerais: Lima Duarte, Distr. Conceição do Ibitipoca, Parque Estadual do Ibitipoca, borda da mata atrás do Centro de Pesquisa, 23-XII-2009, fl., fr., A.J. FernandesJúnior et al. 192 (R); ibid., borda da mata próximo a portaria, 22-III-2010, fr., A.J. Fernandes-Júnior \& G.A.T. Assis 214 (CESJ).

No Brasil ocorre nos Estados de Pernambuco, Bahia, Mato Grosso do Sul, Minas Gerais, Espírito Santo, Rio de Janeiro, São Paulo, Paraná, Santa Catarina e Rio Grande do Sul, no Cerrado e Floresta Atlântica (Bovini et al. 2016).
Sida planicaulis caracteriza-se por apresentar filotaxia dística, ramos aplanados e inflorescência em glomérulo ou flor solitária na axila das folhas (Bovini et al. 2001).

13. Sida rhombifolia L., Sp. Pl: 684. 1753.

Subarbustos ca. 0,4 m alt. Ramos eretos, cilíndricos, pubérulos, tricomas estrelados. Folhas espiraladas; pecíolos 0,3-0,4 cm compr.; estípulas 0,3-0,4 cm compr., iguais entre si, lineares, 1 -nervada; lâminas 0,6-3,1 × 0,3-1,2 cm, 3-nervadas, inteiras, membranáceas a cartáceas, rômbicas, obovadas ou lanceoladas, discolores, ápice agudo ou arredondado, base cuneada ou truncada, margem serreada $2 / 3$ apicais, face adaxial pubescente, tricomas estrelados, face abaxial pubérula, tricomas estrelados; nectários extraflorais ausentes. Inflorescência cimosa em glomérulos ou flores solitárias, axilares; pedicelos 0,5-0,7 cm; epicálice ausente; cálice campanulado, costado, lobado no $1 / 3$ superior, sépalas ca. $0,6 \times 0,4 \mathrm{~cm}$, triangulares, ápice acuminado, externamente pubérulas, tricomas estrelados; pétalas ca. 0,6 $60,4 \mathrm{~cm}$, obovadas, amarelas; estames 20 , tubo estaminal ca. 0,1 cm compr., tricomas glandulares, partes livres dos estames ca. 0,1 cm compr.; epicálice ausente; urcéolo membránaceo ausente; ovário 9 locular, um óvulo por lóculo, estiletes não geniculados, glabros, estigmas 9 , capitados. Esquizocarpo, mericarpos 9, 0,3 ×0,3 cm, com 2 aristas de ca. 0,1 cm compr., glabrescentes, tricomas estrelados; semente única, glabra.

Material examinado: BRASIL. MinAs Gerais: Lima Duarte, Distr. Conceição do Ibitipoca, Parque Estadual do Ibitipoca, campo rupestre próximo ao Centro de Pesquisa, 20-I-2010, fl., fr., A.J. Fernandes-Júnior \& J.E. Assis-Júnior 204 (R).

Espécie de ocorrência pantropical. No Brasil ocorre em todos os Estados (Bovini et al. 2016), especialmente em áreas degradadas.

Sida rhombifolia caracteriza-se pelas lâminas rombiformes, margem serreada nos $2 / 3$ apicais, indumento pubérulo e frutos com nove mericarpos curtamente aristados (Bovini et al. 2001).

14. Sida urens L., Syst. Nat., ed. 10. 2: 1145. 1759. Figuras 3f, 41

Subarbustos ca. 0,4 m alt. Ramos escandentes, cilíndricos, levemente aplanados nos ramos terminais, hirsutos, tricomas simples. Folhas espiraladas; pecíolos 
0,3-0,4 cm compr.; estípulas ca. 0,4 cm compr., iguais entre si, estreito-triangulares, 1-nervada; lâminas 1,2-3,9 × 0,5-2,4 cm, 5-nervadas, inteiras, cartáceas, elípticas ou ovadas, discolores, ápice agudo, base cordada, margem serreada $2 / 3$ apicais, face adaxial velutina, tricomas estrelados, face abaxial tomentosa, tricomas estrelados; nectários extraflorais ausentes. Inflorescência corimbo terminal ou flor solitária axilar; pedicelos ca. $0,7 \mathrm{~cm}$; epicálice ausente; cálice campanulado, costado, lobado no 1/3 superior, sépalas ca. 0,4 ×0,3 cm, triangulares, ápice agudo, externamente pubérulas, tricomas estrelados; pétalas ca. $0,5 \times 0,4 \mathrm{~cm}$, obovadas, amarelas; estames 20 , tubo estaminal ca. 0,2 cm compr., tricomas glandulares, partes livres dos estames ca. 0,1 cm compr.; epicálice ausente; urcéolo membránaceo ausente; ovário 5 locular, um óvulo por lóculo, estiletes não geniculados, glabros, estigmas 5 , capitados. Esquizocarpo, mericarpos 5, ca. $0,3 \times 0,2 \mathrm{~cm}$, múticos a submúticos, glabrescentes, tricomas simples; semente única, tricomas estrelados.

Material examinado: BRASIL. Minas Gerais: Lima Duarte, Distr. Conceição do Ibitipoca, Parque Estadual do Ibitipoca, campo rupestre entre o centro de visitantes/casas de pesquisa, 23-XII-2009, fl., fr., A.J. Fernandes-Júnior et al. 194 (R).

No Brasil ocorre em todo território (Bovini et al. 2016), especialmente em áreas degradadas.

Sida urens caracteriza-se pelas folhas elípticas ou ovadas com base cordada, ramos hirsutos e inflorescências em glomérulos axilares e 5 mericarpos múticos a submúticos (Bovini et al. 2001).

15. Sida viarum A.St.-Hil., Fl. Bras. Mer. 1: 182. 1828. Figuras 3g, 5g-i

Subarbustos ca. 0,2 m alt. Ramos prostrados, cilíndricos, pubérulos, tricomas estrelados presentes. Folhas espiraladas; pecíolos 0,1-0,3 cm compr.; estípulas ca. 0,4-0,5 cm compr., iguais entre si, lineares, nervuras inconspícuas; lâminas 0,7-2,2 ×0,4-0,2 cm, 3 -nervadas, inteiras, cartáceas, elípticas, levemente discolores, ápice agudo, base truncada, margem serreada 2/3 apicais, face adaxial pubescente, tricomas estrelados, face abaxial velutina, tricomas estrelados; nectários extraflorais ausentes. Flores solitárias axilares ou corimbos terminais; pedicelos $0,4-1,0 \mathrm{~cm}$; epicálice ausente; cálice campanulado, costado, lobado na região mediana, sépalas ca. $0,5 \times 0,2 \mathrm{~cm}$, triangulares, ápice agudo, externamente pubérulas com tricomas estrelados; pétalas ca. $0,6 \times 0,4 \mathrm{~cm}$, amarelas com mácula basal vinácea; estames 15 , tubo estaminal ca. $0,1 \mathrm{~cm}$ compr., tricomas glandulares, partes livres dos estames ca. 0,1 cm compr.; epicálice ausente; urcéolo membránaceo ausente; ovário 5 locular, um óvulo por lóculo, estiletes não geniculados, glabros, estigmas 5, capitados. Esquizocarpo, mericarpos 5, ca. $0,2 \times 0,1 \mathrm{~cm}$, submúticos, glabro; semente única, tricomas estrelados.

Material examinado: BRASIL. Minas Gerais: Lima Duarte, Distr. Conceição do Ibitipoca, Parque Estadual do Ibitipoca, camping, transição campo rupestre e mata, 16-V-2010, fl., fr., A.J. Fernandes-Júnior 221 (CESJ); ibid., 16-V-2010, fl., fr., A.J. FernandesJúnior 222 (CESJ).

Espécie endêmica do Brasil ocorre nos Estados do Maranhão, Piauí, Goiás, Mato Grosso do Sul, Minas Gerais, São Paulo, Rio de Janeiro, Paraná e Santa Catarina, na Caatinga, Cerrado e Floresta Atlântica (Bovini et al. 2016).

Sida viarum caracteriza-se por apresentar estípulas lineares persistentes após a queda das folhas, além dos frutos com cinco mericarpos (Fryxell 1988).

16. Triumfetta altheoides Lam., Encyc. Meth. 3: 420. 1789.

Figuras 3h, 5j-k

Arbustos ca. 0,8 m alt. Ramos cilíndricos, glabrescentes a tomentosos, tricomas estrelados. Folhas espiraladas; pecíolos 0,4-6,2 cm compr.; estípulas $0,2-0,5 \mathrm{~cm}$ compr., iguais entre si, ovadas a lanceoladas, ápice acuminado a caudado, 1-nervada; lâminas 1,5-12,1 ×0,6-9,7 cm, 7-9-nervadas, inteiras ou trilobadas, membranáceas, elípticas ou ovadas, discolores, ápice agudo ou acuminado, base truncada ou levemente cordada, margem serreada, face adaxial pubérula, tricomas estrelados, face abaxial pubescente, tricomas estrelados;10 a 14 glândulas nas serras na base das lâminas foliares. Inflorescência cimosa, cimas 3-flora, axilar; pedicelos 0,2-0,3 cm; epicálice ausente; cálice campanulado, não costado, sépalas $0,8-0,9 \times 0,1 \mathrm{~cm}$, oblongas, não cuculadas, externamente pubescentes, tricomas estrelados; pétalas ca. $0,6 \times 0,1 \mathrm{~cm}$, espatuladas, amarelas; estames 21, filetes livres, 0,7-0,8 cm compr., glabros; epicálice ausente; androginóforo ca. $0,1 \mathrm{~cm}$ compr., com 5 glândulas elípticas; urcéolo membránaceo sobre o androginóforo, ovário 7-8 locular, dois óvulos por lóculo, estiletes não geniculados, glabros, estigmas 3-4-fidos, agudos. Núcula 0,6-0,8 cm diâm., aculeada, epicarpo pubescente, tricomas estrelados; sementes 2 , glabras. 
Material examinado: BRASIL. Minas Gerais: Lima Duarte, Distr. Conceição do Ibitipoca, Parque Estadual do Ibitipoca, borda da mata próxima ao restaurante, 20-II-2010, fl., fr., A.J. Fernandes-Júnior \& A.L. Santiago 209 (CESJ).

No Brasil ocorre nos Estados do Amazonas, Pará, Amapá, Paraíba, Pernambuco, Alagoas, Sergipe, Mato Grosso, Mato Grosso do Sul, Distrito Federal, Minas Gerais e Rio de Janeiro, no Cerrado e Floresta Atlântica, Amazônia e Caatinga (Bovini et al. 2016).

Triumfetta altheoides caracteriza-se pelas glândulas conspícuas na base da lâmina foliar, frutos orbiculares com longos acúleos e 7-8 lóculos (Tschá et al. 2002).

Segundo Lay (1950), Triumfetta altheoides ocorre em baixas altitudes e raramente acima dos $200 \mathrm{~m}$, entretanto, no PEIB foi encontrada a ca. $1.200 \mathrm{~m}$ de altitude.

17. Triumfetta rhomboidea Jacq., Enum. Syst. Pl.: 22. 1760.

Figuras 3j, 5n-o

Subarbustos ca. 0,4 m alt. Ramos cilíndricos, glabrescentes a tomentosos, tricomas estrelados. Folhas espiraladas; pecíolos 0,2-0,8 cm compr.; estípulas $0,2-0,3 \mathrm{~cm}$ compr., iguais entre si, lineares a estreito-triangulares, nervuras inconspícuas; lâminas 0,5-3,1 × 0,3-2,4 cm, 5-nervadas, inteiras ou trilobadas, membranáceas a cartáceas, ovadas, rômbicas ou orbiculares, discolores, ápice agudo ou obtuso, base arredondada, margem irregularmente crenado-serreada, face adaxial velutina, tricomas estrelados, face abaxial tomentosa, tricomas estrelados 4 a 6 glândulas nas serras na base da lâminas foliares. Inflorescência cimosa, cimas 3-5-flora, axilar; pedicelos ca. $0,1 \mathrm{~cm}$; epicálice ausente; cálice cuculado, não costado, sépalas $0,4-0,5 \times 0,1 \mathrm{~cm}$, oblongas, cuculadas na porção apical, externamente pubescentes, tricomas estrelados; pétalas ca. $0,4 \times 0,15 \mathrm{~cm}$, espatuladas, às vezes lobadas no ápice, amarelas; estames 14-15, filetes livres, 0,3-0,4 cm compr., glabros; epicálice ausente; androginóforo ca. 0,05 cm compr., com 5 glândulas esféricas; urcéolo membránaceo sobre o androginóforo, ovário 3 locular, dois óvulos por lóculo, estiletes não geniculados, glabros, estigmas 2-fidos, agudos. Núcula 0,3-0,4 cm diâm., aculeada, epicarpo tomentoso, tricomas estrelados; sementes 2 , glabras.

Material examinado: BRASIL. MinAs Gerais: Lima Duarte, Distr. Conceição do Ibitipoca, Parque Estadual do Ibitipoca, campo rupestre próximo ao restaurante, 16-X-2009, fl., fr., A.J. Fernandes-Júnior et al. 183 (CESJ).

No Brasil ocorre no Amazonas, Bahia, Distrito Federal, Minas Gerais, São Paulo e Rio de Janeiro (Lay 1950), no Cerrado e Floresta Atlântica, Amazônia e Caatinga (Bovini et al. 2016).

Triumfetta rhomboidea caracteriza-se pelos botões florais jovens com sépalas profundamente cuculadas e pelos frutos pequenos $0,3-0,4 \mathrm{~cm}$ densamente tomentosos (Lay 1950).

Triumfetta rhomboidea assemelha-se a T. sampaioi Monteiro, diferenciando-se por apresentar 10 a 15 estames, urcéolo membranáceo presente e fruto densamente tomentoso e acúleos glabrescentes, enquanto T. sampaioi apresenta 5 estames, urcéolo membranáceo ausente e frutos densamente plumosos (Lay 1950).

Segundo Lay (1950), Triumfetta bartramia (= Triumfetta rhomboidea) apresenta período de floração e frutificação de julho a novembro, entretanto, no PEIB esta espécie floresceu e frutificou durante o ano todo.Para a determinação da espécie, nós seguimos o conceito de Lay (1950). A maior dificuldade na identificação precisa de Triumfetta rhomboidea foi a incerteza quanto ao tipo nomenclatural. Segundo Miler (1970) e Stafleu \& Cowan (1976-1988) a maioria dos tipos das espécies descritas por Jacquin estão depositados nos herbários BM e W. Desta forma, foi encontrada uma exsicata (BM 795085) indicada como provável tipo de $T$. rhomboidea, na qual apresenta os caracteres diagnósticos que corroboraram com a identificação do espécime coletado no PEIB.

18. Triumfetta semitriloba Jacq., Enum. Syst. P1.: 22. 1760 .

Figuras 3i, 51-m

Arbustos 0,8-1 m alt. Ramos cilíndricos, glabrescentes a velutinos, tricomas estrelados. Folhas espiraladas; pecíolos 0,3-1,3 cm compr.; estípulas 0,3-0,6 cm compr., iguais entre si, lanceoladas, ápice acuminado, 1-nervada; lâminas 0,6-4,7 × 0,5-3,9 cm, 5-7-nervadas, inteiras ou trilobadas, membranáceas, elípticas ou ovadas, discolores, ápice agudo ou acuminado, base arredondada ou levemente cordada, margem irregularmente serreada, face adaxial pubescente, tricomas estrelados, face abaxial velutina, tricomas estrelados; 4 glândulas nas serras na base das lâminas. Inflorescência cimosa, cimas 2-3-flora, axilar; pedicelos 0,3-0,4 cm; 
epicálice ausente; cálice campanulado, não costado, sépalas $0,8-1,0 \times 0,1 \mathrm{~cm}$, oblongas, não cuculadas, externamente pubescentes, tricomas estrelados; pétalas $0,7 \times 0,1-0,15 \mathrm{~cm}$, elípticas, amarelas; estames 20, filetes livres, $0,6-0,7 \mathrm{~cm}$ compr., glabros; epicálice ausente; androginóforo ca. 0,05 cm compr., com 5 glândulas esféricas; urcéolo membránaceo sobre o androginóforo, ovário 3 locular, dois óvulos por lóculo, estiletes não geniculados, glabros, estigmas 1 ou 3-fidos, agudos. Núcula 0,4-0,5 cm diâm., aculeada, epicarpo pubescente, tricomas estrelados; sementes 2 , glabras.

Material examinado: BRASIL. MinAs GERAIS: Lima Duarte, Distr. Conceição do Ibitipoca, Parque Estadual do Ibitipoca, campo rupestre próximo ao restaurante, 16-X-2009, fl., fr., A.J. Fernandes-Júnior 184 (CESJ).

No Brasil ocorre nos Estados do Pará, Amazonas, Maranhão, Piauí, Ceará, Rio Grande do Norte, Paraíba, Bahia, Alagoas, Sergipe, Mato Grosso, Mato Grosso do Sul, Goiás, Distrito Federal, Minas Gerais Espírito Santo, Rio de Janeiro, São Paulo, Paraná, Santa Catarina e Rio Grande do Sul (Bovini et al. 2016) em todos os biomas, predominantemente em áreas degradadas.

Triumfetta semitriloba caracteriza-se pelas folhas trilobadas, pétalas elípticas e frutos triloculados com 2 sementes por lóculo. A espécie mais próxima é Triumfetta altheoides diferenciando-se pelos frutos maiores e com sete a oito lóculos (Lay 1950; Tschá et al. 2002).

Para a determinação da espécie, nós seguimos o conceito de Lay (1950). Assim como em Triumfetta rhomboidea, a maior dificuldade na identificação precisa de Triumfetta semitriloba foi a incerteza quanto ao tipo nomenclatural. Desta forma, foi encontrada uma exsicata (S - 11146), apresentando a inscrição "Specimen Herbare Jacquin" e indicada como provável tipo de T. semitriloba por Ko Ko Lay em 1950, na qual apresenta os caracteres diagnósticos que corroboraram com a identificação do espécime coletado no PEIB.

19. Waltheria indica L. Sp. P1.: 673. 1753. Figura 3k

Subarbustos ca. 0,4 m alt. Ramos eretos, cilíndricos, rugulosos, pubérulos, tricomas estrelados. Folhas espiraladas; pecíolos 0,2-0,8 cm compr.; estípulas 0,3-0,5 cm compr., iguais entre si, lineares a estreito-triangulares, nervuras inconspícuas; lâminas 1,0-4,3 × 0,5-2,2 cm, 5-7-nervadas, inteiras, membranáceas a cartáceas, ovadas ou elípticas, discolores, ápice agudo ou arredondado, base arredondada ou truncada, margem irregularmente serreada, face adaxial velutina, tricomas simples e estrelados, face abaxial tomentosa, tricomas simples e estrelados; nectários extraflorais ausentes. Inflorescência cimosa, glomérulos 15-22-flora, axilares ou terminais; pedicelos menores $0,1 \mathrm{~cm}$; epicálice ausente; cálice tubuloso, não costado, lobado no $1 / 3$ apical, sépalas $0,3 \times 0,1 \mathrm{~cm}$, triangulares, ápice acuminado, externamente pubescentes, tricomas simples; pétalas com unha ca. $0,1 \mathrm{~cm}$ compr., lâmina unguiculadas ca. $0,4 \times 0,1 \mathrm{~cm}$, oblongas, amarelas; estames 5, tubo estaminal 0,2-0,3 cm compr., glabro, filetes concrescidos até o ápice; epicálice ausente; urcéolo membránaceo ausente; ovário 1 locular, um óvulo por lóculo, estilete geniculado, tricomas estrelados, estigma 1, penicilado. Cápsula unicarpelar, 0,2-0,3 cm compr., obovóide, pubescente, tricomas estrelados; semente única, glabra.

Material examinado: BRASIL. Minas Gerais: Lima Duarte, Distr. Conceição do Ibitipoca, Parque Estadual do Ibitipoca, campo rupestre próximo ao Centro de Pesquisa, 16-X-2009, fl., A.J. Fernandes-Júnior et al. 186 (CESJ); ibid., campo rupestre próximo a portaria, 20-I-2010, fl., fr., A.J. Fernandes-Júnior \& J.E. AssisJúnior 205 (R).

A espécie ocorre em todos os Estados do Brasil. Erva daninha comumente encontrada em vegetações secundárias, ao longo de estradas, lugares secos e florestas abertas (Robyns \& Cautrecasas 1964). Waltheria indica é a única espécie do gênero com distribuição pantropical (Cruz 2007).

Waltheria indica caracteriza-se por apresentar inflorescências axilares muito densas, com até 22 flores, ausência de tricomas glandulares nos ramos e nas folhas e por possuir flores homostílicas, um caráter raro no gênero (Cruz 2007).

20. Wissadula parviflora (A.St-Hil.) R.E.Fries, Kongl. Svenska Vetensk. Acad. Handl. 43(4): 46. 1908. Figura 21

Arbustos 1-2 m alt. Ramos eretos, cilíndricos, pubescentes, tricomas estrelados. Folhas espiraladas; pecíolos 0,8-13,3 cm compr.; estípulas 0,8-0,9 cm compr., iguais entre si, lanceoladas, ápice acuminado, 3 -nervadas; lâminas 1,2-15,1 × 1,9-10,3 cm, 7-9-nervadas, inteiras, membranáceas, ovadas, discolores, ápice acuminado, base cordada, margem inteira, face adaxial glabras ou pubescentes, tricomas 
simples e estrelados associados, face abaxial velutina, tricomas estrelados; nectários extraflorais ausentes. Inflorescência cimosa, cimas 2-3-flora, terminais; pedicelos 1,2-2,2 cm; epicálice ausente; cálice campanulado, não costado, lobado na região mediana, sépalas ca. 0,2 ×0,2 cm, ovadas, ápice agudo, externamente pubescentes, tricomas estrelados; pétalas ca. $0,8 \times 0,5 \mathrm{~cm}$, obovadas, amarelas; estames 25-30, tubo estaminal ca. 0,1 cm compr., glabro, partes livres dos estames $0,2-0,3 \mathrm{~cm}$ compr.; epicálice ausente; urcéolo membránaceo ausente; ovário 3-5 locular, 3 óvulos por lóculo, 2 colaterais superiores e um inferior, estiletes não geniculados, glabros, estigmas 3-5, capitados. Esquizocarpo, 3-5 mericarpos, 0,6-1,1 × 0,5-0,7 cm, com aristas 2, de 0,2-0,3 cm compr., com uma constrição formando 2 cavidades, pubérulos, tricomas simples; sementes 3, uma na contrição inferior e duas na contrição superior, tricomas simples.

Material examinado: BRASIL. Minas Gerais: Lima Duarte, Distr. Conceição do Ibitipoca, Parque Estadual do Ibitipoca, borda da mata próxima a portaria, 17-V-2006, fl., fr., R.C. Forzza 4185 (RB).

No Brasil ocorre nos Estados da Bahia, Minas Gerais, São Paulo Rio de Janeiro, Paraná, Santa Catarina e Rio Grande do Sul, na Floresta Atlântica (Bovini \& Baumgratz 2016).

Wissadula parviflora caracteriza-se pelos grandes mericarpos com longas aristas (0,2-0,3 cm compr.) e tricomas simples na face adaxial das lâminas foliares (Bovini \& Baumgratz 2016).

\section{Considerações finais}

Foram reconhecidas 20 espécies de Malvaceae na área de estudo, as quais estão distribuídas em 10 gêneros: Callianthe, Helicteres, Hibiscus, Luehea, Pavonia, Peltaea, Sida, Triumfetta, Waltheria e Wissadula.

Os gêneros registrados na área de estudo podem ser diferenciados, principalmente, pela presença de epicálice (Hibiscus, Luehea, Pavonia e Peltaea) ou sua ausência (Callianthe, Helicteres, Sida, Triumfetta, Waltheria e Wissadula) e pelo tipo de fruto (esquizocarpo em Callianthe, Pavonia, Peltaea, Sida e Wissadula, cápsula em Hibiscus, Luehea, Helicteres e Waltheria e núcula em Triumfetta).

Todas as espécies encontradas no Parque Estadual do Ibitipoca são nativas do Brasil, entretanto, Hibiscus kitaibelifolius, Pavonia sagittata, Pavonia viscosa, Sida glaziovii, Sida harleyi, Sida lonchitis, são as únicas espécies exclusivamente brasileiras (BFG 2015). Além disso, Sida rhombifolia e Waltheria indica são as únicas espécies encontradas com distribuição pantropical (Krapovickas 2007, Cruz 2007).

As espécies estão representadas por poucos indivíduos no PEIB, sendo que a maioria foi encontrada em locais onde ocorre ação antrópica, principalmente por pisoteio, já que muitas espécies estão nas margens das trilhas onde há intenso fluxo turístico no parque. Os dados apresentados neste trabalho podem ajudar no plano de manejo do PEIB, já que a maioria das espécies possui baixa densidade populacional e foram encontradas em trilhas.

\section{Agradecimentos}

O primeiro autor agradece ao Conselho Nacional de Desenvolvimento Científico e Tecnológico (CNPq) e ao Programa de Capacitação Institucional (MPEG/ MCTI); ao IEF-MG pela licença de coleta no PEIB e aos guardas-parque; ao Dr. Ruy José Valka Alves (MN-UFRJ) pelas observações e contribuições ao trabalho; ao biólogo Thiago Martins do NAGEAUFJF pela confecção do mapa, além dos curadores dos herbários consultados.

\section{Literatura citada}

Alverson, W.A., Whitlock, B.A., Nyeffeler, R., Bayer, C. \& Baum, D.A. 1999. Phylogeny of Malvales: evidence from ndhF sequence data. American Journal of Botany 86: 1474-1486.

APG IV. 2016. An update of the Angiosperm Phylogeny Group classification for the orders and families of flowering plants: APG IV. Botanical Journal of the Linnean Society 181: 1-20.

Bayer, C., Fay, M.F., Bruijn, A.Y., Savolainen, V., Morton, C.M., Kubitzki, K., Alverson, W.S. \& Chase, M.W. 1999. Support for an expanded family concept of Malvaceae within a recumscicribed order Malvales: a combined analysis of plastid atpB and rbcl DNA sequences. Botanical Journal of the Linnean Society 129: 267-303.

Bayer, C. \& Kubitzki, K. 2003. Malvaceae. In: The families and genera of vascular plants. Springer, Berlin, v. 5, pp. 225-311.

BFG (The Brazilian Flora Group). 2015. Growing knowledge: an overview of Seed Plant diversity in Brazil. Rodriguésia 66: 1085-1113.

Bovini, M.G., Carvalho-Okano, R.M. \& Vieira, M.F. 2001. Malvaceae A. Juss. no Parque Estadual do Rio Doce, MG, Brasil. Rodriguésia 52: 17-47. 
Bovini, M.G. \& Baumgratz, J.F.A. 2016. Taxonomic revision of Wissadula (Malvoideae, Malvaceae) in Brazil. Phytotaxa 243: 201-234.

Bovini, M.G., Esteves, G.L., Duarte, M.C., Takeuchi, C., Kuntz, J. 2016. Malvaceae in Lista de Espécies da Flora do Brasil. Jardim Botânico do Rio de Janeiro. Disponível em http://floradobrasil.jbrj.gov.br/jabot/ floradobrasil/FB156 (acesso em 19-III-2016).

CETEC (Fundação Centro Tecnológico de Minas Gerais). 1983. Diagnóstico Ambiental de Minas Gerais. Série de Publicações Técnicas, 10. Belo Horizonte.

Costa, M.R.C., Hermann, G., Martins, C.M., Lins, L.V. \& Lamas, I.R. 1998. Biodiversidade em Minas Gerais: um atlas para sua conservação. Fundação Biodiversistas, Belo Horizonte.

Cristóbal, C.L. 2001. Taxonomia del gênero Helicteres (Sterculiaceae). Revisión de las especies americanas. Bonplandia 11: 1-206.

Cristóbal, C.L. 2006. Flora de Grão-Mogol, Minas Gerais: Sterculiaceae. Boletim do Instituto de Botânica 24: 107-113.

Cronquist, A. 1988. The evolution and classification of flowering plants. 2 ed. New York Botanical Garden, New York.

Cruz, F.R. 2007. Sterculiaceae Vent. no estado de São Paulo. Dissertação de Mestrado. Instituto de Botânica de São Paulo, São Paulo.

Cunha, M.C.S. 1985. Revisão das espécies do gênero Luehea Willd. (Tiliaceae) ocorrentes no Estado do Rio de Janeiro. Sellowia 37: 5-41.

Esteves, G.L. 1986. A Ordem Malvales na Serra do Cipó, Minas Gerais, Brasil. Dissertação de Mestrado. Universidade de São Paulo, São Paulo.

Esteves, G.L. 2003. Flora de Grão-Mogol, Minas Gerais: Bombacaceae. Boletim do Instituto de Botânica 21: 123-126.

Esteves, G.L \& Ferrucci, M.S. 2006. Flora de GrãoMogol, Minas Gerais: Tiliaceae. Boletim do Instituto de Botânica 24: 119-120.

Esteves, G.L. \& Krapovickas, A. 2009. Flora de GrãoMogol, Minas Gerais: Malvaceae. Boletim do Instituto de Botânica 27: 63-71.

Fernandes-Júnior, A.J. 2016. Revisão taxonômica do gênero Peltaea (C.Presl) Standl. (Malvaceae, Malvoideae) no Brasil e filogenia de Peltaea e gêneros afins. Tese de Doutorado. Instituto de Botânica de São Paulo, São Paulo.

Forzza, R.C., Menini-Neto, L., Salimena, F.R. e Zappi, D. 2013. Flora do Parque Estadual do Ibitipoca e seu entorno. Editora UFJF, Juiz de Fora.

Fryxell, P.A. 1988. Malvaceae of Mexico. In: Systematic Botany Monographs. Ann Arbor, Michigan, v. 25, pp. 1-522.

Fryxell, P.A. 1999. Pavonia Cavanilles (Malvaceae). Flora Neotropica Monograph 76: 1-285.
Harris, J.G. \& Harris, M.W. 2001. Plant identification terminology. 2 ed. Spring Lake, Utah.

Judd, W.S. \& Manchester, S.R. 1997. Circumscription of Malvaceae (Malvales) as determined by a preliminary cladistic analysis of morphological, anatomical, palynological, and chemical characters. Brittonia 49: 384-405.

Krapovickas, A. \& Cristóbal, C.L. 1965. Revisión del género Peltaea (Malvaceae). Kurtziana 2: 135-216.

Krapovickas, A. \& Fryxell, P.A. 2004. Las especies sudamericanas de Hibiscus Secc. Furcaria DC. (Malvaceae-Hibisceae). Bonplandia 13: 35-115.

Krapovickas, A. 2007. Novedades em el gênero Sida (Malvaceae, Tribu Malveae). Bonplandia 16: 193-208.

Lay, K.K. 1950. The American species of Triumfetta L. Annals of the Missouri Botanical Garden 37: 315-395.

Lorenzi, H. 2008. Plantas daninhas do Brasil: terrestres, aquáticas, parasitas e tóxicas. 4 ed. Nova Odessa, São Paulo.

Miller, H.S. 1970. The herbarium of Aylmer Bourke Lambert: notes on its acquisition, dispersal, and present whereabouts. Taxon 19: 489-553.

Nyffeler, R., Bayer, C., Alverson, W.S., Yen, A., Whitlock, B.A., Chase, M.W. \& Baum, D.A. 2005. Phylogenetic analysis of the Malvadendrina clade (Malvaceae s.l.) based on plastid DNA sequences. Organisms, Diversity \& Evolution 5: 109-123.

Robyns, A. \& Cautrecasas, J. 1964. Flora of Panama. Sterculiaceae. Annals of the Missouri Botanical Garden 51: 69-107.

Salimena, F.R.G. 1996. Aspectos fitofisionômicos e vegetacionais do Parque Estadual do Ibitipoca, Minas Gerais, Brasil. In: G.C. Rocha (coord.). Anais do $1^{\circ}$ Seminário de Pesquisa sobre o Parque Estadual de Ibitipoca. Núcleo de Pesquisa em Zoneamento Ambiental da Universidade Federal de Juiz de Fora, Juiz de Fora, pp. 60-61.

Saint-Hilaire, A. 1828. Malvaceae. In: Flora Brasiliae Meridionalis. A. Belin, Paris, v. 1, pp. 1-256.

Silva, J.X. \& Zaidan, R.T. 2004. Geoprocessamento e análise ambiental: aplicações. Bertrand Brasil, Rio de Janeiro.

Simpson, M.G. 2006. Plant Systematics. 1 ed. Elsevier Academic Press, London.

Stafleu. F.A. \& Cowan, R.S. 1976/1988. Taxonomic Literature. Scheltema \& Holkema. 7 v. Utrecht.

Thiers, B. [continuously updated]. 2016. Index herbariorium: A global directory of publish herbaria and associated staff. New York Botanical Garden's Virtual Herbarium. Disponível em http//sweetgum.nybg.org/ih (acesso em 10-III-2016).

Tschá, M.C., Sales, M.F. \& Esteves, G.L. 2002. Tiliaceae Juss. no Estado de Pernambuco, Brasil. Hoehnea 29: $1-18$. 